\title{
PREDICTION OF IN VIVO BONE FORMING POTENCY OF BONE MARROW- DERIVED HUMAN MESENCHYMAL STEM CELLS
}

\author{
Patricia Janicki, Stephane Boeuf, Eric Steck, Marcus Egermann, Philip Kasten ${ }^{\S}$ and Wiltrud Richter*
}

Research Centre for Experimental Orthopaedics, Orthopaedic University Hospital Heidelberg, Heidelberg, Germany ${ }^{\S}$ Current address: Department of Orthopaedic Surgery, University of Dresden, Dresden, Germany

\begin{abstract}
Human mesenchymal stem cells (MSC) have attracted much attention for tissue regeneration including repair of non-healing bone defects. Heterogeneity of MSC cultures and considerable donor variability however, still preclude standardised production of MSC and point on functional deficits for some human MSC populations. We aimed to identify functional correlates of donor-dependency of bone formation in order to develop a potency assay predicting the therapeutic capacity of human MSC before clinical transplantation. MSC from 29 donors were characterised in vitro and results were correlated to bone formation potency in a beta-tricalcium-phosphate ( $\beta$-TCP)-scaffold after subcutaneous implantation into immunocompromised mice.

In contrast to osteogenic in vitro differentiation parameters, a doubling time below 43.23 hours allowed to predict ectopic bone formation at high sensitivity $(81.8 \%)$ and specificity (100\%). Enriched conditions adapted from embryonic stem cell expansion rescued bone formation of inferior MSC populations while growth arrest of potent MSC by mitomycin $\mathrm{C}$ abolished bone formation, establishing a causal relationship between neo-bone formation and growth. Gene expression profiling confirmed a key role for proliferation status for the bone forming ability suggesting that a rate limiting anabolism and open chromatin determined and predicted the therapeutic potency of culture-expanded MSC. Proliferation-based potency testing and switch to enriched expansion conditions may pave the way for standardised production of MSC for bone repair.
\end{abstract}

Key words: Bone tissue engineering, beta-tricalciumphosphate, heterotopic bone formation, mesenchymal stem cell, cell proliferation, prediction, microarray.

*Address for correspondence:

Wiltrud Richter

Research Centre for Experimental Orthopaedics

Department of Orthopaedics

Trauma Surgery and Paraplegia

Orthopaedic University Hospital Heidelberg

Schlierbacher Landstrasse 200a,

D-69118 Heidelberg, Germany

Telephone Number: +49-(0)-6221-969253

FAX Number: +49-(0)-6221-969288

E-mail: Wiltrud.Richter@med.uni-heidelberg.de

\section{Introduction}

Mesenchymal stem cells (MSC) support the homeostasis of mesenchymal tissues and their trophic and mesengenic activities bear a high therapeutic potential for tissue regeneration. Reflecting the complexity of the stromal system in bone marrow, MSC populations expanded from marrow aspirates are heterogeneous in nature with the exact composition depending on the donor (Rickard et al., 1996; Majors et al., 1997; Muschler et al., 2001), the individual aspirate (Lazarus et al., 1997; Muschler et al., 1997; Phinney et al., 1999; Muschler et al., 2001; Hernigou et al., 2006), applied isolation methods and expansion conditions, the latter of which differ largely among investigators (Phinney, 2002; Shahdadfar et al., 2005; Sotiropoulou et al., 2006; Mannello and Tonti, 2007; Wagner and Ho, 2007). Cloned populations of MSC demonstrate that only part of the cells is multipotent while the remaining population shows varied phenotypes (Russell et al., 2010). Increasing interest in the clinical use of MSC, however, demands standardised methods to produce cell populations of high regeneration capacity and accurate control of their therapeutic potential (Phinney, 2007; Caplan, 2009; Tarte et al., 2010). This includes the necessity to determine the therapeutic potency of every MSC population by an adequate assay before it may be transplanted.

MSC-based tissue engineering approaches have attracted attention in the context of bone repair since they were successfully used to bridge large bone defects in animal models (Bruder et al., 1998a; Bruder et al., 1998b). Bone formation by bone marrow-derived human MSC is, however, less robust compared to other species according to classical tests of heterotopic bone formation (Krebsbach et al., 1997), which further document a donor variability for human MSC populations (Mendes et al., 2002; Mendes et al., 2004; Siddappa et al., 2007; Siddappa et al., 2008; Matsushima et al., 2009). Parameters such as age, gender, medication or disease of the donor and the location of bone marrow harvest (Muschler et al., 2001; Stenderup et al., 2003; McLain et al., 2005; Siddappa et al., 2007) were considered as reasons for this undesired character of human MSC, pointing out functional deficits for human MSC populations from some donors compared to others. On the other hand, expansion conditions are likely to influence the overall cell composition (Martin et al., 1997; Muraglia et al., 1998; Kuznetsov et al., 2000) and the fitness of cells at the time of transplantation may strongly influence their actual bone forming potency in vivo. It is conceivable that patients treated with suboptimal MSC populations may develop poorer regeneration results or that cell-based treatment may even fail in spite of high 
costs inflicted with this therapy. So far no tests are available to predict the potency of individual bone marrow-derived MSC populations to form bone in vivo in order to pave the way for standardised clinical use of MSC in bone repair. In addition, no rate-limiting cellular or molecular correlates of in vivo bone formation have been identified for human MSC.

While many studies addressed donor variations regarding growth and osteogenic in vitro potential of human MSC (Jaiswal et al., 1997; Digirolamo et al., 1999; Phinney et al., 1999; Mendes et al., 2004; Siddappa et al., 2007), and predictors of successful in vitro osteogenesis of MSC have recently been reported (Platt et al., 2009; Pietila et al., 2010), no irrefutable positive correlation between in vitro parameters or molecular signatures of bone marrow-derived human MSC populations and in vivo bone formation have been identified.

This study was undertaken to unravel rate-limiting cellular and molecular aspects underlying the ectopic bone formation ability of human MSC. This test requires the use of a scaffold and a recently characterised beta-tricalciumphosphate ( $\beta$-TCP) was chosen, since it demonstrated superior potency compared with a hydroxyapatite/ tricalcium-phosphate (HA/TCP) ceramic (Janicki et al., 2010). In order to extract predictors applicable as clinically relevant potency assays, our approach was to expand human MSC from a large cohort of donors under standardised conditions. Donor characteristics, growth properties, in vitro differentiation potential and gene expression profile of each MSC population were determined and correlated to the in vivo bone formation. We identify a rate-limiting doubling time and molecular signature of open chromatin as highly predictive for in vivo bone formation, and establish a causal relationship between bone formation and growth allowing the rescue of inferior MSC populations for therapeutic use.

\section{Materials and Methods}

\section{Cell isolation and cultivation}

Human bone marrow cells were aspirated from the iliac crest or femur of 29 donors. Informed consent was obtained from all individuals and the study was approved by the local ethics committee. MSC were isolated from fresh bone marrow samples as described previously (Dickhut et al., 2009). In short, density gradient isolated mononuclear cells were seeded in expansion medium (High-glucose Dulbecco's modified Eagle's medium (DMEM, Invitrogen, Karlsruhe, Germany), $2 \%$ foetal calf serum (FCS, Biochrom, Germany), 40 \% MCDB201, 0.02 $\mu \mathrm{M}$ dexamethasone, $0.1 \mathrm{mM}$ ascorbic acid 2-phosphate, $2 \%$ insulin-transferrin-sodium selenite media supplement (all Sigma-Aldrich, Steinheim, Germany), $100 \mathrm{U} / \mathrm{mL}$ penicillin and $100 \mu \mathrm{g} / \mathrm{mL}$ streptomycin (Biochrom, Berlin, Germany), $10 \mathrm{ng} / \mathrm{mL}$ recombinant human epidermal growth factor and recombinant human platelet-derived growth factor BB (both Strathmann Biotech, Hamburg, Germany) (Reyes et al., 2001) at a density of $5 \times 10^{5}$ cells $/ \mathrm{cm}^{2}$. Where indicated, mononucleated cells $(\mathrm{n}=5$ donors) were simultaneously seeded at a density of 1.25 $\mathrm{x} 10^{5}$ cells per $\mathrm{cm}^{2}$ into $0.1 \%$ gelatin-coated flasks in an embryonic stem cell (ES) medium (DMEM, $12.5 \%$ FCS, $2 \mathrm{mM}$ L-glutamine, $1 \%$ non essential amino acids, $0.1 \%$ 2-mercaptoethanol (Invitrogen), $100 \mathrm{U} / \mathrm{mL}$ penicillin, 100 $\mu \mathrm{g} / \mathrm{mL}$ streptomycin, $4 \mathrm{ng} / \mathrm{mL}$ human fibroblast growth factor-2 (Active Bioscience, Hamburg, Germany)). $33 \%$ of the ES medium was conditioned for $48 \mathrm{~h}$ by primary mouse embryo fibroblasts (PMEF-NL, Millipore, Molsheim, France). Standard culturing conditions were used $\left(37^{\circ} \mathrm{C}\right.$, $6 \% \mathrm{CO}_{2}$ ) and the medium was changed twice a week. For culturing MSC were replated at a density of 4-6 $\times 10^{3}$ cells $/ \mathrm{cm}^{2}$.

Cell surface marker expression profiles and the multipotency were standardly determined for MSC populations, as described previously (Winter et al., 2003; Dickhut et al., 2009). Depending on the experimental setting, cells from passage 1, 2, 3 or 5 were used. For inhibition of cell proliferation at passage $2(n=4$ donors) cells were treated for $2 \mathrm{~h}$ with medium containing $20 \mu \mathrm{g} /$ $\mathrm{mL}$ mitomycin $\mathrm{C}$ (Sigma-Aldrich) and washed twice with PBS. Untreated and mitomycin C-treated MSC were then incubated with $1 \%$ trypsin/ethylenediaminetetraacetic acid (Biochrom) solution, harvested, centrifuged, resuspended in PBS and used for experiments like WST-1 assay (replated in culture medium), osteogenesis in vitro (replated in induction medium) or ectopic transplantation (seeded on $\beta$-TCP granules).

\section{Heterotopic in vivo bone formation assay}

To allow broad characterisation of MSC from the first 20 donors in multiple assays at the time of transplantation, about $3 \times 10^{7}$ cells were required from each donor. This number was usually reached at passage 3 (P3) allowing all assays to be started including $\beta$-TCP/MSC transplantation to assess heterotopic bone formation after 8 weeks.

Phase-pure $(>95 \%) \beta$-TCP $\left(\mathrm{Ca}_{3}\left(\mathrm{PO}_{4}\right)_{2}\right)$ granules (0.5-0.7 mm, RMS Foundation, Bettlach, Switzerland) with a porosity of $60 \%$, macropores of $100-500 \mu \mathrm{m}$ and not specified micropores were sterilised for $6 \mathrm{~h}$ at 120 ${ }^{\circ} \mathrm{C}$, and $10 \mathrm{mg}$ granules were mixed with $1 \times 10^{6} \mathrm{MSC}$ and fibrin glue as described previously (Janicki et al., 2010). Seeding efficiency was $98-99 \%$ according to counting of MSC remaining after a first washing step of the constructs. Freshly prepared three-dimensional constructs consisting of $\beta$-TCP and MSC (2-4 per donor, $\mathrm{n}=29$ donors) were transplanted for 8 weeks into paravertebral subcutaneous pouches of 6-8 week old male severe combined immunodeficiency (SCID) mice ( $\mathrm{n}=$ 45) (Charles River, Sulzfeld, Germany). According to the number of MSC populations cultured simultaneously, $\beta$-TCP/MSC constructs of one or two donors were transplanted into one animal. Two to four subcutaneous pouches were prepared per mouse and one construct per pouch was implanted. All procedures were performed according to the European Laboratory Animal Science guidelines. The experimental protocol was approved by the local animal experimentation committee (35-9185.81G95/06). All animals survived the experimental period of 8 weeks. 


\section{Histological evaluation}

$\beta$-TCP/MSC explants were fixed in Bouin's solution for 2 days providing fixation and partial decalcification in one step (Kuznetsov et al., 2000). Further, explants were dehydrated using graded alcohol series and embedded in paraffin. Sections were stained with haematoxylin and eosin (H\&E, Chroma, Münster, Germany). Human cells were identified by detection of human-specific genomic Alu repeats using a digoxygenin-labelled probe, as previously described (Steck et al., 2010). Briefly, paraffin sections were deparaffinised, rehydrated in alcohol and digested in $50 \mathrm{ng} / \mathrm{mL}$ proteinase $\mathrm{K}$ (Fermentas, St. LeonRot, Germany). After washing with PBS, sections were treated with $0.1 \mathrm{M}$ triethanolamine hydrochloride $\mathrm{pH} 8$ (Sigma-Aldrich) in $0.25 \%$ acetic acid and pre-hybridised in hybridisation buffer containing $4 \mathrm{x}$ saline-sodium citrate (SSC), 1x Denhardt's solution, $5 \%$ dextrane sulphate, $50 \%$ deionised formamide, $100 \mu \mathrm{g} / \mathrm{mL}$ salmon sperm DNA and aqua bidest. Hybridisation buffer was replaced by fresh hybridisation buffer containing $0.2 \mathrm{ng} /$ $\mu \mathrm{L}$ dioxigenin-labelled probe, sections were denaturated and immediately cooled. Hybridisation was carried out for $16 \mathrm{~h}$ in a wet chamber. Sections were washed twice in $2 \mathrm{x}$ SSC and twice in $0.1 \mathrm{x}$ SSC. Positive signals were detected by using anti-digoxygenin alkaline phosphataseconjugated Fab fragments and nitro-blue-tetrazolium/5Bromo-4-chloro-3-indolyl-phosphate (Roche, Mannheim, Germany) as substrate. Sections were counterstained with fast red (Chroma).

\section{Osteogenic in vitro differentiation of human MSC}

Per donor ( $\mathrm{n}=29$ donors) $3.5 \times 10^{4}$ MSC per well were seeded in quadruplicates into 24-well plates and were incubated with high-glucose DMEM supplemented with $10 \%$ FCS, $0.1 \mu \mathrm{M}$ dexamethasone, $0.17 \mathrm{mM}$ ascorbic acid 2-phosphate, $10 \mathrm{mM} \beta$-glycerophosphate (Sigma-Aldrich) and $1 \%$ penicillin/streptomycin. At four time points (day $1,7,14,21)$ two wells each were used for assessment of alkaline phosphatase (ALP) enzyme activity while two wells served to quantify mineralisation using alizarin red S staining.

\section{Alkaline phosphatase activity assay}

Cells were lysed with $1 \%$ triton X-100 detergent (SigmaAldrich) in PBS, scraped off the plate and stored at -80 ${ }^{\circ} \mathrm{C}$ (two wells per donor and time point). ALP activity was assessed in duplicates by diluting two $50 \mu \mathrm{L}$ samples with $50 \mu \mathrm{L}$ ALP buffer $(0.1 \mathrm{M}$ glycine, $1 \mathrm{mM} \mathrm{MgCl}, 1$ $\mathrm{mM} \mathrm{ZnCl}{ }_{2}, \mathrm{pH}$ 10.4) each before incubation with 100 $\mu \mathrm{L}$ ALP buffer plus $1 \mathrm{mg} / \mathrm{mL}$ p-nitrophenylphosphate (p-NPP). The conversion to $\mathrm{p}$-nitrophenol (p-NP) was measured spectrophotometrically at 405/490 nm after $1 \mathrm{~h}$ of incubation. Total protein concentration was determined by the Micro $\mathrm{BCA}^{\mathrm{TM}}$ Protein Assay Reagent Kit (Pierce Biotechnology, Rockford, IL, USA) according to manufacturer's instructions. The amount of p-NP divided by the amount of total protein normalised the specific amount of ALP.

\section{Alizarin red $\mathbf{S}$ staining for calcification}

Cells were fixed with $70 \%$ ethanol and stained with $0.5 \%$ alizarin red $\mathrm{S}$ (Chroma) (two wells per donor and time point). Monolayers were treated with $10 \%$ hexadecetylpyridinium-chloride-monohydrate (CPC) and the eluted solution of each well was measured spectrophotometrically in duplicates at $570 \mathrm{~nm}$. The amount of CPC was divided by the amount of total protein to normalise for cell quantity.

\section{Evaluation of generation time}

Generation time was calculated for each MSC donor population $(n=29)$ using the following formula: $G=$ $(\log 2 \times \mathrm{T}) /(\log \mathrm{Y}-\log \mathrm{X}) . \mathrm{G}$ stands for generation time [hours], $\mathrm{T}$ for time in culture per passage [hours], Y for cell number at harvesting time point, $\mathrm{X}$ for cell number at seeding time point.

\section{${ }^{3} \mathrm{H}$-thymidine proliferation assay}

To analyse the proliferation rate, $4 \times 10^{3} \mathrm{MSC}$ were seeded into 96-wells in triplicates in expansion medium $(\mathrm{n}=29$ donors). After $24 \mathrm{~h}$, medium was replaced by fresh medium containing $0.25 \mu \mathrm{Ci}$ of [methyl- ${ }^{3} \mathrm{H}$ ]-thymidine (GE Healthcare, München, Germany) per well. After additional $18 \mathrm{~h}$ cells were washed, lysed with $1 \%$ triton X-100 and transferred into tubes containing $2 \mathrm{~mL}$ scintillation cocktail (Perkin Elmer, Waltham, MA, USA). Radioactivity was measured by a WinSpectral 1414 Liquid Scintillation Counter (Perkin Elmer).

\section{WST-1 assay}

To analyse the vitality, $4 \times 10^{3} \mathrm{MSC}$ were seeded into 96-wells in triplicates in expansion medium $(n=2$ donors). Medium was replaced $24 \mathrm{~h}$ after seeding by $90 \mu \mathrm{L}$ fresh medium and supplemented with $10 \mu \mathrm{L}$ of 4-[3-(4-Iodophenyl)-2-(4-nitrophenyl)-2H-5-tetrazolio]1,3-benzene disulfonate (WST-1, Roche, Mannheim, Germany) per well. MSC were incubated for $1 \mathrm{~h}$ at $37{ }^{\circ} \mathrm{C}$ according to manufacturer's instructions and the cleavage of WST-1 to formazan was measured spectrophotometrically at $450 \mathrm{~nm}$.

\section{Microarray analysis}

Total RNA was isolated out of 0.6-3 x106 expanded MSC ( $\mathrm{n}=8$ populations with and $\mathrm{n}=8$ populations without the ability to form ectopic bone) at the time point of transplantation using RNeasy Mini kit according to manufacturer's instructions (Qiagen, Hilden, Germany). The microarray analysis (Illumina Human Sentrix, Human Ref_8 v3.0) was performed at the Genomic \& Proteomics Core Facility of the German Cancer Research Centre in Heidelberg, Germany. Briefly, cDNA was synthesised from $0.5 \mu \mathrm{g}$ of total RNA, followed by an amplification/ labelling step to synthesise a biotin-labelled cRNA. After purification and quality control, $0.75 \mu \mathrm{L}$ of the labelled probes were hybridised to the BeadChips consisting of 24.495 transcripts and transcript variants. Data analysis was done by normalisation of the signals using the 
quantile normalisation algorithm without background subtraction, and differentially regulated genes were defined by calculating the standard deviation differences of a given probe in a one-by-one comparison of both groups. Cluster analysis was adopted to find differences between MSC with and without bone forming capability. Log transformed signal intensities were calculated and submitted to average linkage hierarchical clustering using the Cluster and Treeview software (Eisen et al., 1998). Significantly different expressed genes were annotated using open source Database for Annotation, Visualisation and Integrated Discovery (DAVID v6.7 (Dennis et al., 2003; Huang et al., 2009)).

\section{Quantitative real-time polymerase chain reaction}

First-strand cDNA was synthesised from $2 \mu \mathrm{g}$ of total RNA using Omniscript reverse transcriptase $(0.2 \mathrm{U} / \mu \mathrm{L})$ and oligo $(\mathrm{dT})$ primers $(1 \mu \mathrm{M})$ (Qiagen) according to the manufacturer's instructions. The cDNA was quantified with a LightCycler 3 using LightCycler FastStart DNA Master SYBR Green I Kit (both Roche Diagnostics) according to the manufacturer's instructions. The following primers were used: $\beta$-actin: 5'-CTCTTCCAGCCTTCCTTCCT-3', 5' - C G A T C C A C A C G G A G T A C T T G - 3' ; CDC20: 5'-CATTCGCATCTGGAATGTGT-3', 5' - G C C T GA G A T GA G C T C C T T G TA - 3 '; HIST2H2AA3: 5'-TACATGGCTGCGGTCCTC-3', 5 '-GGAGGTGACGAGGGATGAT-3'. The $\beta$-actin signal was used for normalisation.

\section{Statistical analysis}

Differences in outcome parameters were assessed by non-parametric two-tailed Mann-Whitney $U$ test and a $p \leq 0.05$ was considered significant. For correlations between two categorial variables, the non-parametric Spearman's rank correlation $\left(\mathrm{r}_{\mathrm{s}}\right)$ was applied. To reflect the degree of linear relationship between two variables, the Pearson's correlation $\left(r_{p}\right)$ was adopted. To determine thresholds for ALP values and generation time in regard to bone formation, the receiver-operating characteristic (ROC) analysis was performed calculating sensitivity/ specificity pairs by varying the decision threshold levels over the entire range of results (Metz et al., 1973; Zweig and Campbell, 1993). Data analysis was performed with SPSS for Windows 16.0 (SPSS Inc., Chicago, IL, USA).

\section{Results}

\section{Donor variability of heterotopic bone formation}

While explants derived from the same donor showed little variation in neo-bone formation, a huge variability was evident for constructs from different donors. Overall, MSC from 11 out of 20 donors had formed bone (Table 1) with no evident correlation to gender but with a negative correlation to donor age $\left(\mathrm{r}_{\mathrm{s}}=-0.550, p=0.012\right)$. Accordingly, MSC capable to form bone (Fig. 1A) were derived from significantly younger donors (mean age 29.6, $\mathrm{SEM} \pm 4.08, p=0.012$ ) compared to MSC which failed

Table 1. Donor characteristics and MSC in vitro parameters in relation to bone formation listed by increasing generation time.

\begin{tabular}{|c|c|c|c|c|c|c|c|}
\hline Donor & Age & Gender & $\begin{array}{l}\text { Ectopic } \\
\text { bone } \\
\text { formation }\end{array}$ & $\begin{array}{l}\text { Generation } \\
\text { time* }[\mathrm{h}]\end{array}$ & $\begin{array}{l}\text { Days in } \\
\text { culture }\end{array}$ & $\begin{array}{l}\text { Max. ALP activity** } \\
{[\text { ng substrate/ } \mu \mathrm{g}} \\
\text { protein]/min }\end{array}$ & $\begin{array}{l}\text { Max. calcification** } \\
{[\mu \mathrm{g} \text { calcium } / \mu \mathrm{g}} \\
\text { protein] }\end{array}$ \\
\hline 1 & 19 & $\mathrm{~m}$ & yes & 27.38 & 16 & 8.27 & 28.50 \\
\hline 2 & 42 & $\mathrm{~m}$ & yes & 29.40 & 17 & 4.85 & 23.08 \\
\hline 3 & 23 & $\mathrm{f}$ & yes & 29.81 & 16 & 16.90 & 73.11 \\
\hline $4 '$ & 41 & $\mathrm{~m}$ & yes & 30.28 & 12 & 13.87 & 17.02 \\
\hline 5 & 14 & $\mathrm{~m}$ & yes & 30.48 & 15 & 10.04 & 14.47 \\
\hline 6 & 19 & $\mathrm{~m}$ & yes & 33.86 & 14 & 23.56 & 5.51 \\
\hline 7 & 26 & $\mathrm{f}$ & yes & 33.99 & 17 & 3.75 & 37.05 \\
\hline 8 & 30 & $\mathrm{~m}$ & yes & 36.00 & 17 & 9.30 & 10.07 \\
\hline 9 & 24 & $\mathrm{f}$ & yes & 42.94 & 14 & 5.90 & 15.33 \\
\hline & & & & |------------------ & & & \\
\hline 10 & 61 & $\mathrm{f}$ & no & 43.52 & 18 & 1.04 & 46.33 \\
\hline $11^{\prime}$ & 61 & $\mathrm{~m}$ & yes & 48.26 & 19 & 2.33 & 16.57 \\
\hline 12 & 56 & $\mathrm{~m}$ & no & 48.88 & 19 & 0.56 & 42.47 \\
\hline $13^{\prime}$ & 27 & $\mathrm{f}$ & yes & 55.38 & 18 & 4.41 & 19.54 \\
\hline 14 & 43 & $\mathrm{~m}$ & no & 62.37 & 19 & 1.08 & 24.80 \\
\hline 15 & 41 & $\mathrm{f}$ & no & 62.74 & 19 & 0.43 & 22.56 \\
\hline 16 & 56 & $\mathrm{~m}$ & no & 66.77 & 26 & 0.79 & 31.62 \\
\hline 17 & 11 & $\mathrm{f}$ & no & 101.46 & 25 & 0.75 & 26.36 \\
\hline 18 & 46 & $\mathrm{f}$ & no & 104.64 & 19 & 1.65 & 12.69 \\
\hline $19^{\prime}$ & 74 & $\mathrm{f}$ & no & 107.49 & 18 & 2.93 & 23.35 \\
\hline 20 & 74 & $\mathrm{~m}$ & no & 189.62 & 25 & 0.24 & 44.38 \\
\hline
\end{tabular}

*at time point of implantation, **during osteogenic in vitro differentiation, ' = not included in gene expression analysis since used for experiments in Table 2, optimal threshold (43.23 h/PD). 

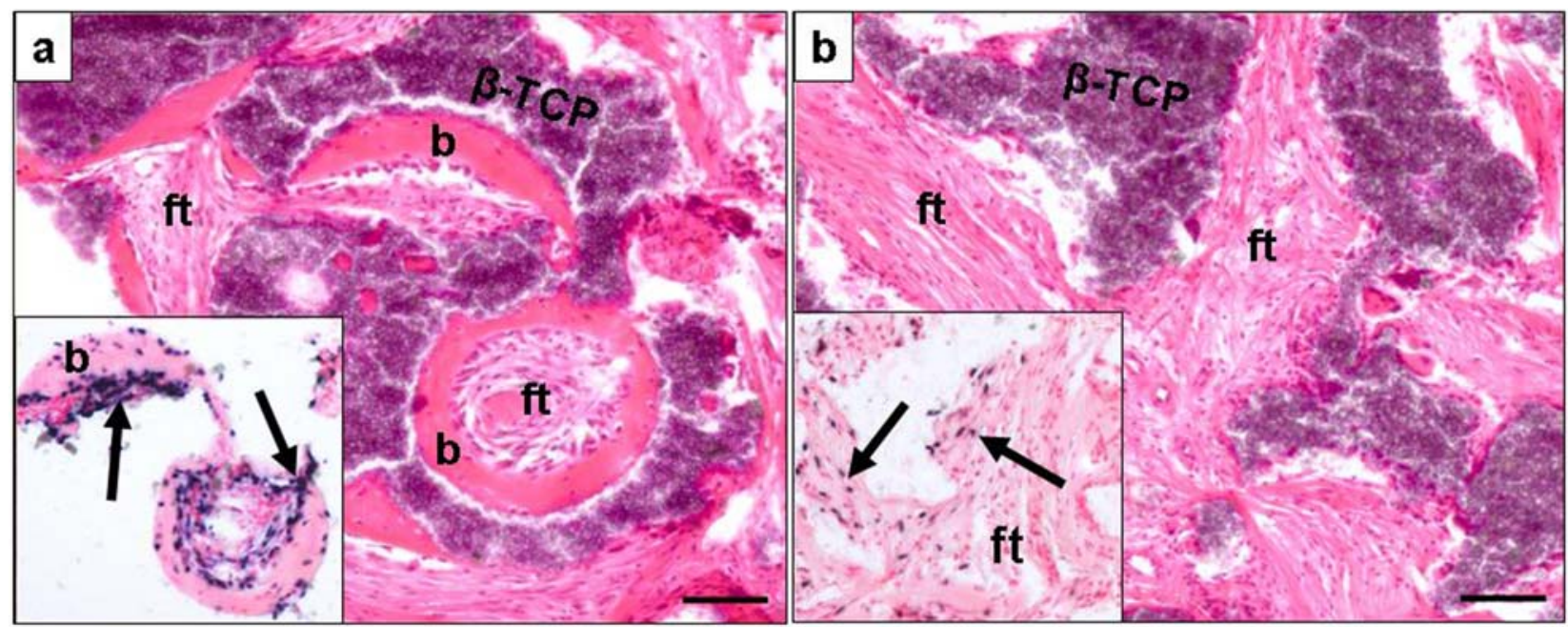

C

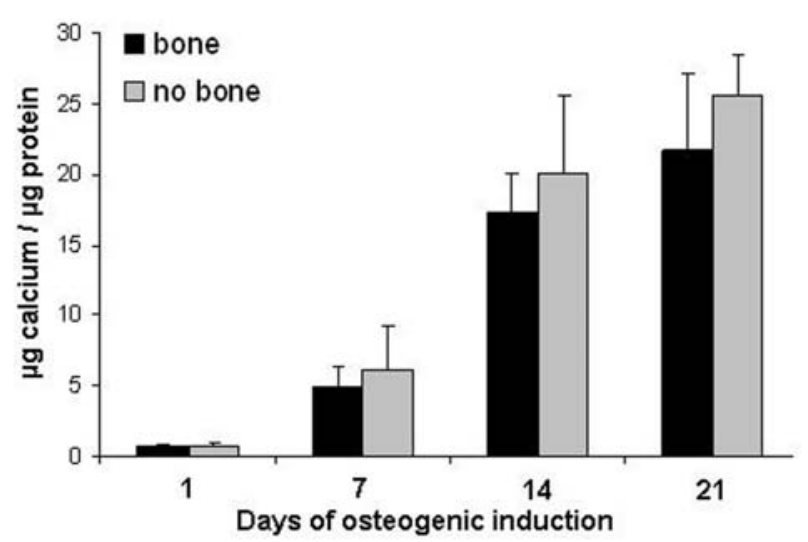

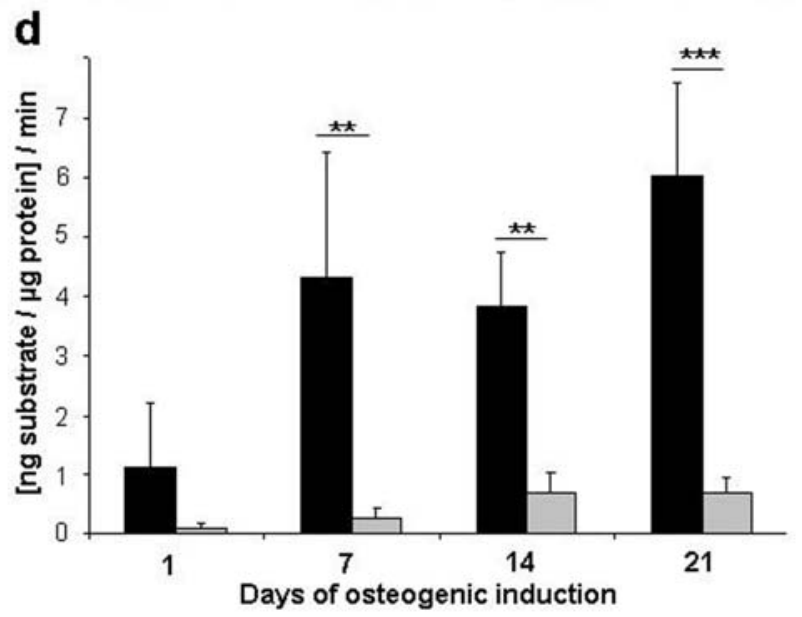

Fig. 1. The standard osteogenic in vitro mineralisation assay does not correlate with in vivo bone formation. (a-b) Representative pictures of H\&E-stained histological sections of $\beta$-TCP/MSC explants with (a) and without (b) bone formation. Human-specific Alu in situ hybridisation revealed human origin of bone forming cells (a, inset, arrows) and only few human cells within the fibrous tissue of explants without bone formation (b, inset, arrows). (c) Alizarin red S-stained calcium-deposition during $21 \mathrm{~d}$ of osteogenic in vitro differentiation. All MSC populations were able to deposit a calcium-rich extracellular matrix in vitro, independent of their bone forming ability in vivo. (d) ALP activity in cell lysates was measured during osteogenic monolayer differentiation on day $7(* * p=0.004)$, $14(* * p=0.002)$ and $21(* * * p=0.001)$ of induction. MSC which formed bone in vivo showed significantly higher ALP activity during $21 \mathrm{~d}$ of osteogenic in vitro induction. $\mathrm{b}=$ heterotopic bone, $\mathrm{ft}=$ fibrous tissue. Scale bar: 100 $\mu \mathrm{m}$. Error bars represent standard error of the mean.

in bone formation (Fig. 1B) (mean age 51.3, SEM \pm 6.45 , Table 1). Osteoblast-like cells depositing bone in the pores of the $\beta$-TCP granules were of human origin (Fig. 1A, inset). Only few or no human cells were identified within the fibrous tissue of $\beta$-TCP/MSC constructs from the non-bone forming group (Fig. 1B, inset). This indicated that MSC which were incapable to form bone migrated away from the constructs or died. Vascular structures were apparent in all constructs independent of bone formation. MSC-free $\beta$-TCP granules or carrier-free MSC never revealed bone structures (data not shown). There was no correlation between the site of bone marrow harvest or the pathology of donors, like osteoarthritis or other diseases, and the bone forming potency of the MSC.

\section{Correlation of in vitro osteogenesis with in vivo bone formation}

In parallel to transplantation, MSC populations of 20 donors were subjected to osteogenic in vitro conditions for 21 days in culture. Osteogenesis resulted in a timedependent increase of ALP activity and calcium deposition for all donor MSC. Mineralisation was not significantly different between MSC groups with or without bone formation ( $p \leq 0.112$ ) (Fig. 1C).

ALP activity revealed a high donor variability during osteogenic in vitro induction with bone-forming MSC populations reaching significantly higher ALP values at day $7(p=0.004)$, day $14(p=0.002)$ and day $21(p=$ 0.001 ) (Fig. 1D). Thus, a strong positive correlation $\left(\mathrm{r}_{\mathrm{s}}\right.$ 
a

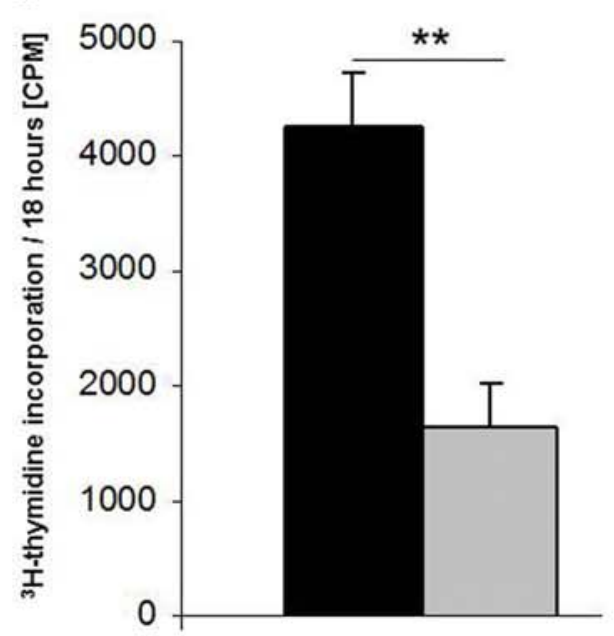

C

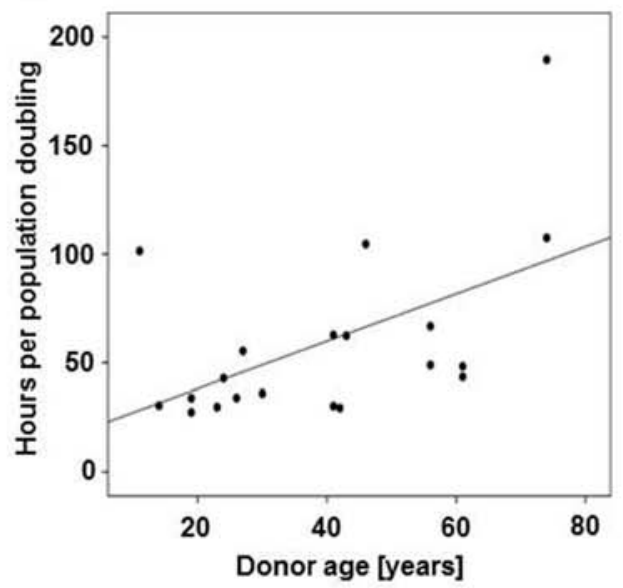

b

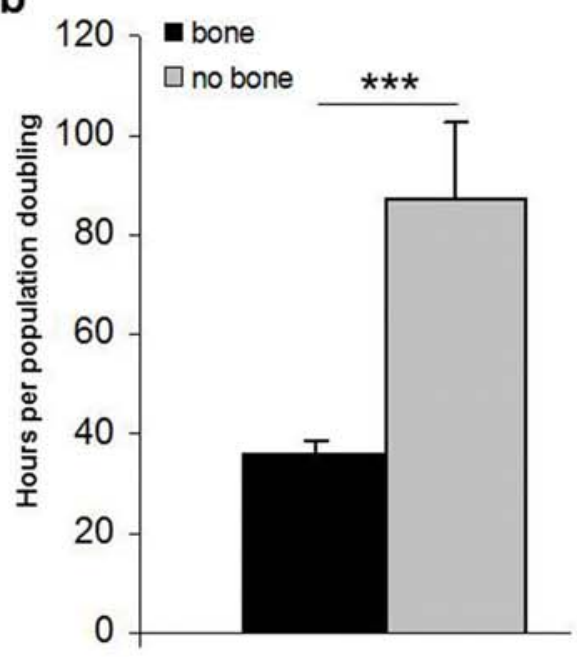

d

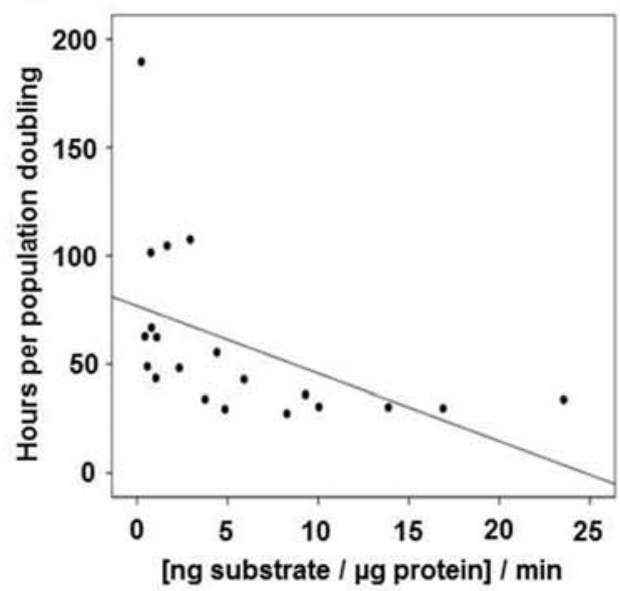

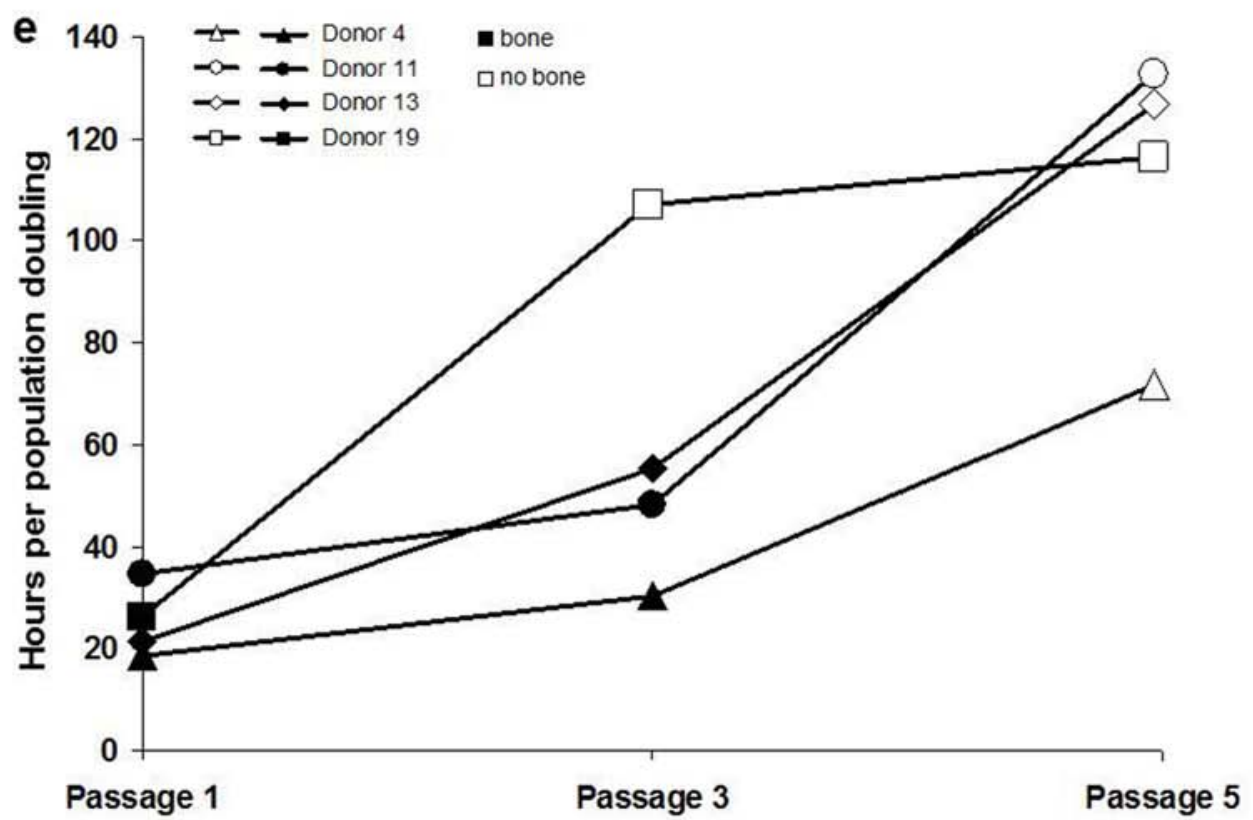

Fig. 2. Growth characteristics of undifferentiated MSC prior to transplantation. (a) Bone forming MSC populations incorporated significantly more ${ }^{3} \mathrm{H}$-thymidine $(* * p=0.002)$ within $18 \mathrm{~h}$ in vitro and (b) revealed a significantly shorter $(* * * p \leq 0.001)$ generation time than MSC without the ability to form bone. Bars represent standard error of the mean. (c) Generation time of expanded MSC correlated positively with donor age $\left(\mathrm{r}_{\mathrm{p}}=0.529, p=0.016\right)$ and (d) negatively $\left(\mathrm{r}_{\mathrm{p}}=-0.694, p \leq 0.001\right)$ with the maximum ALP activity during osteogenic in vitro differentiation. (e) Increased doubling time correlated with loss of bone formation during serial passaging of MSC. 
Table 2. Generation time and maximum ALP activity of MSC during serial passaging (P1-P5).

\begin{tabular}{|l|l|l|l|l|l|l|}
\hline & \multicolumn{3}{|c|}{} & \multicolumn{3}{l|}{$\begin{array}{l}\text { Max. ALP activity** } \\
{[\text { ng substrate/ } \mu \text { g protein]/min }}\end{array}$} \\
\hline Donor & P1 & P3 & P5 & P1 & P3 & P5 \\
\hline 4 & $\mathbf{1 8 . 5 7}$ & $\mathbf{2 0 . 2 8}$ & 72.17 & $\mathbf{1 5 . 5 4}$ & $\mathbf{1 3 . 8 7}$ & 21.89 \\
\hline 11 & $\mathbf{3 4 . 7 1}$ & $\mathbf{4 8 . 2 6}$ & 133.14 & $\mathbf{6 . 4 9}$ & $\mathbf{2 . 3 3}$ & 10.40 \\
\hline 13 & $\mathbf{2 1 . 2 2}$ & $\mathbf{5 5 . 3 8}$ & 127.09 & $\mathbf{1 0 . 0 0}$ & $\mathbf{4 . 4 1}$ & 13.84 \\
\hline 19 & $\mathbf{2 6 . 3 5}$ & 107.49 & 116.80 & $\mathbf{7 . 7 5}$ & 2.93 & 8.31 \\
\hline
\end{tabular}

*At time point of implantation, **During osteogenic in vitro differentiation, bold $=$ samples that showed bone formation in vivo.

Table 3. Generation time and time in culture of MSC expanded under standard versus enriched culture conditions.

\begin{tabular}{|l|l|l|l|l|l|}
\hline & & & Expansion medium & & \\
Donor & Age & Gender & $\begin{array}{l}\text { Conditioned ES medium } \\
\text { Generation time* }[\mathrm{h}]\end{array}$ & Generation time* $[\mathrm{h}]$ & Days in culture \\
\hline 21 & 23 & $\mathrm{f}$ & 46.13 & $\mathbf{3 8 . 9 6}$ & 13 \\
\hline 22 & 46 & $\mathrm{~m}$ & 50.88 & $\mathbf{3 4 . 4 0}$ & 16 \\
\hline 23 & 64 & $\mathrm{f}$ & $\mathbf{5 9 . 4 5}$ & $\mathbf{3 2 . 5 7}$ & 11 \\
\hline 24 & 36 & $\mathrm{f}$ & 65.87 & $\mathbf{3 9 . 0 8}$ & 18 \\
\hline 25 & 84 & $\mathrm{~m}$ & 68.85 & $\mathbf{4 0 . 2 5}$ & 13 \\
\hline
\end{tabular}

*At time point of implantation, bold = samples that showed bone formation in vivo.

$=0.845, p \leq 0.001)$ existed between bone formation and in vitro ALP induction after osteogenic stimulation. ROC analysis was applied in order to determine an optimal ALP threshold level which would best predict bone formation in our model. The optimal decision threshold for peak ALP values was $3.34 \mathrm{ng}$ substrate/minute and $\mu \mathrm{g}$ protein. All MSC populations with values below this cut-off level failed to form bone (100.0\% specificity), while all bone forming samples except one (donor 11, Table 1), had maximal ALP values above this threshold, corresponding to a test sensitivity of $90.9 \%$.

\section{Correlation of growth rate with bone formation}

In contrast to the outcome of an in vitro osteogenic assay, growth parameters are known before transplantation of MSC and are, thus, attractive as possible predictors of bone formation capacity in a clinical setting. MSC samples forming bone revealed a significantly higher ${ }^{3} \mathrm{H}$-thymidine incorporation into DNA (2.58-fold, $p=0.002)$ (Fig. 2A) and thus a higher proliferation rate than MSC incapable to form bone. Bone forming MSC had a significantly shorter mean generation time $(36.16 \mathrm{~h}$ per population doubling (h/PD), SEM $\pm 2.7, p \leq 0.001)$ than MSC without bone formation (87.49 h/PD, SEM \pm 15.1 ) (Fig. 2B) revealing a strong correlation between generation time and bone formation $\left(r_{s}=-0.810, p \leq 0.001\right)$. The optimal decision level for prediction of bone formation based on generation time was $43.23 \mathrm{~h} / \mathrm{PD}$ according to ROC analysis (dashed line, Table 1). All MSC failing to form bone grew more slowly than this threshold (100\% specificity) while all but 2 donor populations forming bone were faster than this threshold (donor 11 and 13, Table 1) yielding a test sensitivity of $81.8 \%$. Thus, at the chosen conditions, doubling time at the day of transplantation would have correctly predicted in vivo bone formation capability of 18 out of 20 donors without any false positives.

Since faster growing MSC populations reached P3 earlier than cells growing more slowly, bone forming MSC were transplanted after a significantly shorter time in culture (mean 15.91 days, $\mathrm{SEM} \pm 0.61$ ) than MSC of the other group (20.89 days, $\mathrm{SEM} \pm 1.12, p \leq 0.001)$. All MSC cultured for 17 days or less formed bone (Table 1) while MSC expanded for more than 19 days never formed bone under our expansion conditions. Age and ALP activity correlated significantly with the proliferation rate of MSC (Fig. 2C-D) demonstrating that these parameters represent no independent determinants of bone forming ability.

\section{Serial passaging and in vivo bone formation}

We next challenged the determined decision levels for ALP-based and proliferation-based prediction by testing the bone forming ability of four MSC populations during serial passaging (Table 2). Generation time of each MSC population increased with every passage and bone formation capacity declined in parallel. While all $\mathrm{P} 1$ cells formed ectopic bone (Fig. 2E, closed symbols), one MSC population had lost its bone formation ability at $\mathrm{P} 3$ while at P5 all four MSC populations were negative (Fig. 2E, open symbols). The generation time of about $43 \mathrm{~h} / \mathrm{PD}$ extracted before, again, correctly predicted bone formation for 10 out of these 12 transplanted MSC populations (P1, P3, P5 from four donors each) with no false positive results. 

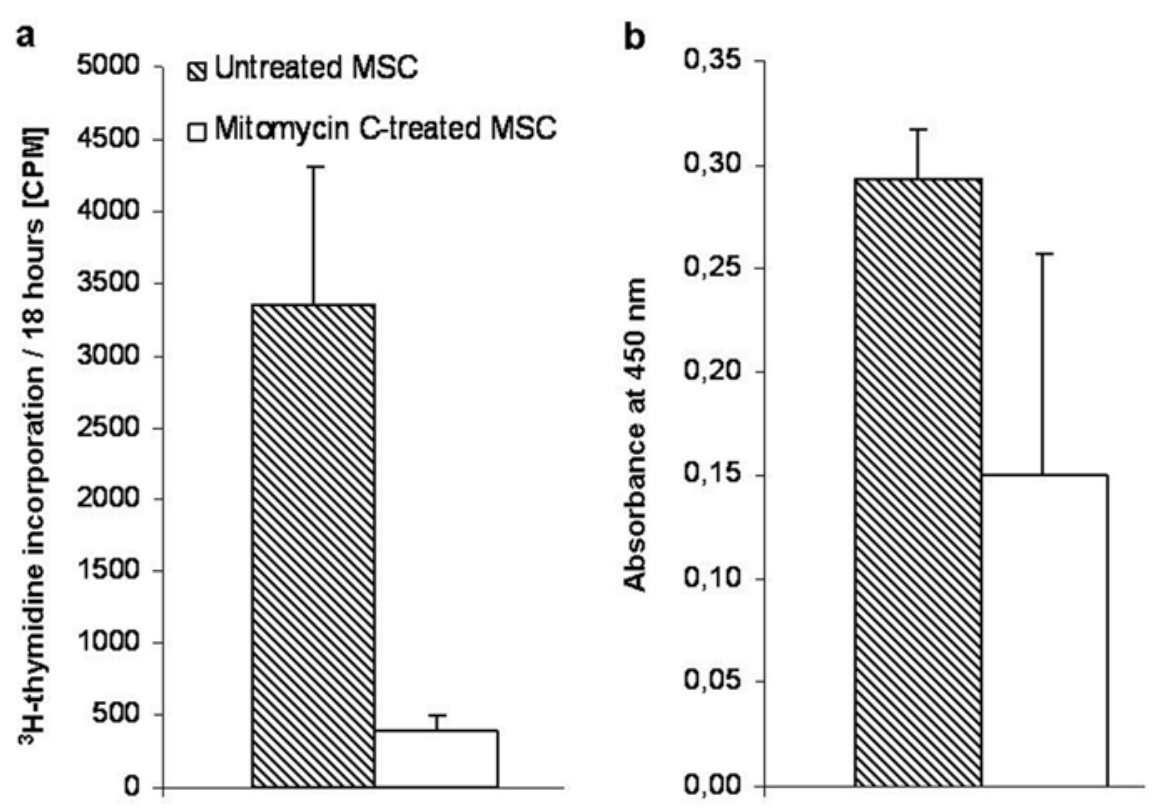

Fig. 3. Arrest of cell proliferation by mitomycin C. (a) DNA synthesis dropped to $12 \%$ by mitomycin C-treatment (white bar) compared to MSC cultivated in the expansion medium (striped bar, $n=4)$. (b) Cell metabolism assessed by a WST-1 assay was reduced by half in mitomycin C-treated MSC compared to untreated controls $(n=2)$. Bars represent standard error of the mean.

Prediction based on in vitro ALP activity, however, did not pass this test. Although ALP activity was high in all P1 populations and decreased at P3, it increased again at P5 reaching the highest values for cells without bone forming ability (Table 2). Thus, in contrast to generation time, the in vitro ALP response to osteogenic induction turned out to be no robust predictor of heterotopic bone formation.

\section{Modulation of proliferation rate can rescue in vivo bone formation}

In order to look for a causal relationship between mitotic activity and heterotopic bone formation capacity, we tried to rescue inferior MSC populations by improved expansion under enhanced conditions. Slower versus faster growing MSC were produced from the same marrow aspirates by expansion in culture medium versus enriched conditions adapted from embryonal stem (ES) cell protocols (donor 21-25, Table 3). MSC in ES-medium incorporated on average 8.5 -fold more ${ }^{3} \mathrm{H}$-thymidine (not shown) and revealed 1.58-fold shorter generation times (Table 3) compared to MSC under standard expansion. At the same time point (near confluence at P2, day 11-18, depending on the donor) both MSC populations from each donor were harvested and transplanted. While all ES-medium expanded MSC grew faster than $43 \mathrm{~h} / \mathrm{PD}$ and formed heterotopic bone, the corresponding standard cultures remained above $43 \mathrm{~h} / \mathrm{PD}$ and 4 of these $5 \mathrm{MSC}$ populations could not form bone as predicted according to generation time. Altogether this demonstrated that enhancing the proliferation rate rescued bone formation of inferior MSC suggesting a causal relationship between proliferation rate and in vivo bone formation.

\section{No bone formation without proliferation}

To decide whether growth is a prerequisite for bone formation, human MSC (donor 26-29, aged 17-79 years) with a permissive generation time at P2 were treated for 2 $\mathrm{h}$ with the mitotic inhibitor mitomycin $\mathrm{C}$ which irreversibly blocks DNA synthesis and inhibits proliferation. DNA synthesis dropped to $12 \%$ by this treatment within $18 \mathrm{~h}$ (Fig. 3A, $\mathrm{n}=4$ donors) while values for cell metabolism were reduced by half(Fig. $3 \mathrm{~B}, \mathrm{n}=2$ donors), demonstrating that mitomycin $\mathrm{C}$-treated cells were alive but unable to proliferate. After ectopic transplantation of constructs consisting of $10 \mathrm{mg} \beta$-TCP and either treated or untreated MSC ( 1 x $10^{6}$ cells, P2), respectively, none of the mitomycin $\mathrm{C}$-treated MSC formed bone, while the corresponding untreated MSC (generation times 21.89 to $34.43 \mathrm{~h} / \mathrm{PD}$ ) all formed bone. During osteogenic in vitro induction, however, all mitomycin C-treated cells were able to deposit a mineralised matrix (data not shown).

\section{Molecular correlates of in vivo bone formation}

In order to extract molecular markers as potential predictors, gene expression profiling was performed for 16 MSC populations from Table 1, half of which had shown bone formation capability in P3. Cluster analysis identified a group of 4 closely related MSC populations which had formed bone and 3 closely related MSC populations which did not form bone. Gene signatures of these two groups differed by 311 genes at significance level. When this selection of genes was used for clustering of all 16 samples (Fig. 4A) two groups of 8 samples each were obtained in which all bone forming MSC were separated from all nonbone forming cells except one wrong sample in each group. 
Of the 311 differentially expressed genes, 230 were higher expressed in bone-forming MSC (1.8-fold to 34.9-fold) including many cell cycle-associated genes like CDC20, CDCA7, CDC45, CDCA5 and the cyclins CCNB2, CCNA2, CCNE2, CCNF associated with cell proliferation (Table 4). Functional annotation of these genes by the DAVID program (Dennis et al., 2003; Huang et al., 2009) revealed mitosis, cell division, DNA replication and related pathways as main biological functions.

In the group of MSC that did not form bone, 81 genes were higher expressed. These included genes of the histone clusters HIST1H1C, HIST1H4H, HIST2H2AC, HIST2H2AA3, and molecules relevant for the formation of nucleosomes, dense chromatin, or capable of protein-DNAcomplex formation. Some genes were associated with apoptosis (Table 5). Selected transcripts were confirmed by RT-PCR to have a significantly different expression level between the bone and not bone forming group (Fig. 4B). In summary, molecular analysis corroborated cell growth and an open chromatin as main determinant of in vivo bone formation making further investigation into molecular prediction assays promising.

\section{Discussion}

We here present a strategy to predict the heterotopic bone forming ability of human MSC populations in a $\beta$-TCP scaffold by a surprisingly simple potency test relying on determination of the generation time of MSC at the time of transplantation. Our study, for the first time, establishes a causal relationship between proliferation ability and heterotopic in vivo bone formation potency of human MSC and identifies a rate limiting proliferative activity as crucial for the success of neo-bone formation. A threshold set for generation time $(43.23 \mathrm{~h})$ at the time of MSC transplantation allowed, at our expansion conditions, to correctly predict the in vivo outcome of more than 20 donor populations with high specificity and sensitivity. This threshold proved also valuable when MSC were expanded for different passages and under altered expansion conditions. Proliferation rate also predicted the loss of heterotopic bone formation with increasing passage seen here in agreement with a recent study (Agata et al., 2010) suggesting that time in culture is an alternate growth-dependent parameter of bone formation. Overwhelming molecular evidence from genome-wide transcriptome analysis confirmed growth and an open chromatin status as the major functional correlates of heterotopic bone formation. Altogether our data suggest that, in order to be successful, MSC have to be transplanted in a time window in which sufficient cells show high anabolism as major prerequisites for trophic and osteogenic activity at the site of transplantation. Beside its simplicity, a sensitivity of about $80 \%$ at a specificity of 100 $\%$ under our conditions makes this assay quite attractive in the context of clinical use.

Why is growth such a dominant parameter in a heterotopic osteogenic differentiation model where osteoinductive growth factors, appropriate mechanical a

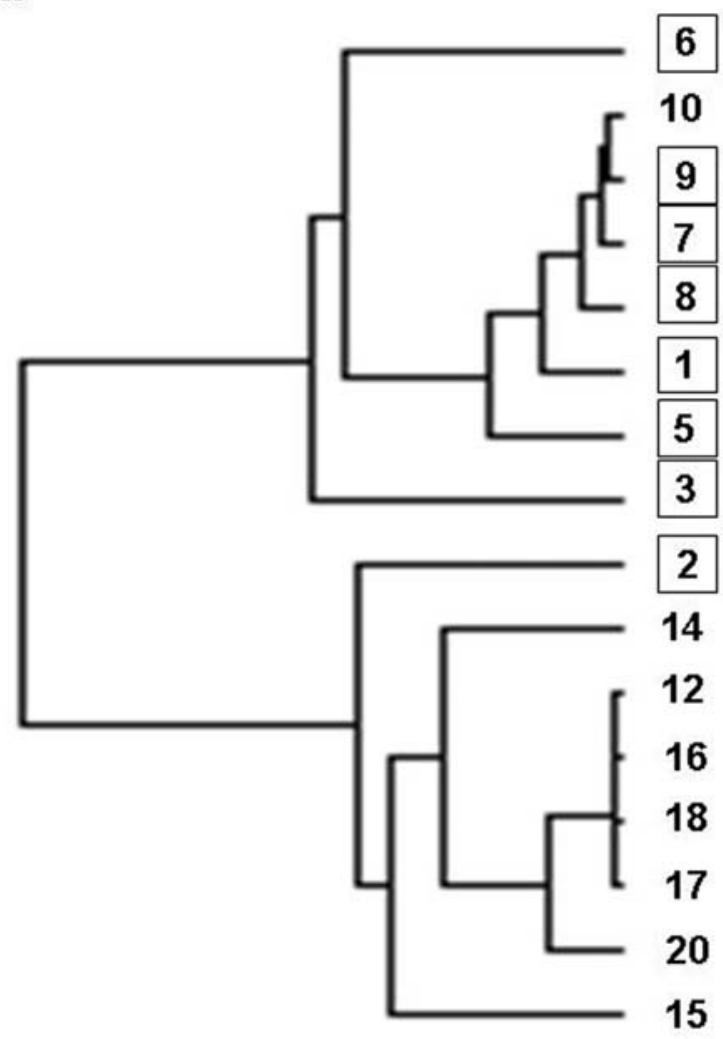

b

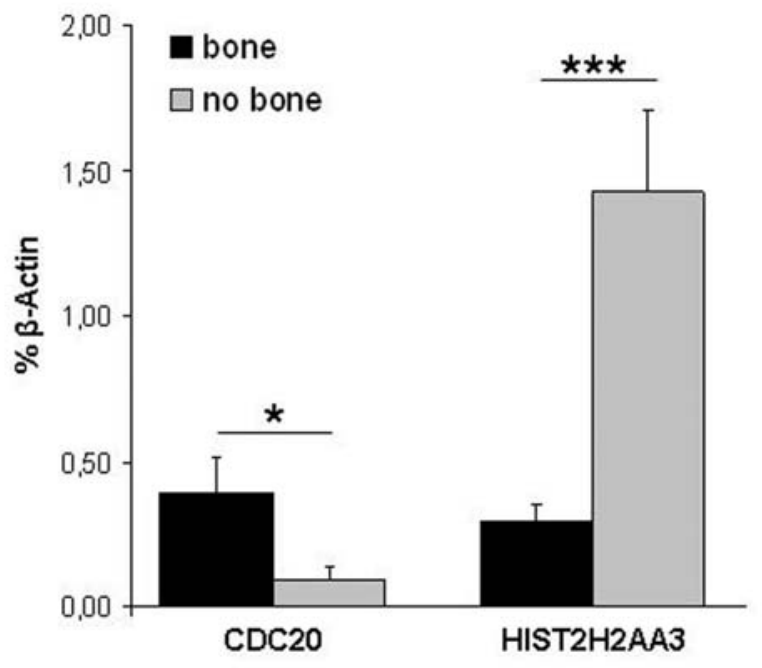

Fig. 4. Gene expression analysis of expanded MSC at the time point of transplantation. Genome wide expression analysis was carried out for MSC populations of 16 donors. (a) Cluster analysis based on 311 genes of MSC populations with (numbers in boxes) and without the ability to form ectopic bone in vivo. (b) Real-time PCR analysis confirmed the expression differences of two selected genes obtained by the array analysis. CDC20 was higher expressed $(* p=0.015)$ in the bone forming group, whereas HIST2H2AA3 was higher $(* p$ $=0.001)$ in the MSC group without bone formation. Bars represent standard error of the mean. 
Table 4a. Genes with significantly higher expression in expanded MSC capable to form bone after subcutaneous transplantation in SCID mice (part 1).

\begin{tabular}{|c|c|c|c|}
\hline Gene symbol & Gene name & $\begin{array}{l}\text { Fold change } \\
\text { to non-bone } \\
\text { forming MSC } \\
\text { populations }\end{array}$ & Reference \\
\hline CDC20 & CDC20 cell division cycle 20 homolog & 34.95 & $\underline{\text { NM } 001255.1}$ \\
\hline UBE2C & Ubiquitin-conjugating enzyme E2C & 23.93 & NM_181800.1 \\
\hline PRC1 & Protein regulator of cytokinesis 1 & 23.09 & NM 003981.2 \\
\hline TOP2A & Topoisomerase (DNA) II alpha $170 \mathrm{kDa}$ & 19.87 & NM_001067.2 \\
\hline KIAA0101 & KIAA0101 (KIAA0101), transcript variant 1 & 18.43 & NM 014736.4 \\
\hline KIF20A & Kinesin family member $20 \mathrm{~A}$ & 16.84 & NM 005733.1 \\
\hline CCNB2 & Cyclin B2 & 16.13 & $\underline{\text { NM } 004701.2}$ \\
\hline TYMS & Thymidylate synthetase & 14.58 & $\underline{\text { NM_001071.1 }}$ \\
\hline NUSAP1 & Nucleolar and spindle associated protein 1 & 14.38 & NM 016359.2 \\
\hline PTTG1 & Pituitary tumor-transforming 1 & 12.91 & $\underline{\text { NM } 004219.2}$ \\
\hline CCNA2 & Cyclin A2 & 12.80 & NM 001237.2 \\
\hline BIRC5 & Baculoviral IAP repeat-containing 5 (survivin) & 12.78 & NM_001168.2 \\
\hline KIFC1 & Kinesin family member $\mathrm{C} 1$ & 12.72 & $\underline{\text { NM } 002263.2}$ \\
\hline Pfs2 & GINS complex subunit 2 & 12.39 & NM 016095.1 \\
\hline UBE2C & Ubiquitin-conjugating enzyme $\mathrm{E} 2 \mathrm{C}$ & 12.23 & NM_181803.1 \\
\hline CDCA7 & Cell division cycle associated 7 & 11.74 & NM_145810.1 \\
\hline CDC45L & CDC45 cell division cycle 45 -like & 11.23 & $\underline{\text { NM } 003504.3}$ \\
\hline CDCA5 & Cell division cycle associated 5 & 10.71 & NM 080668.2 \\
\hline HMMR & Hyaluronan-mediated motility receptor & 10.61 & NM 012485.1 \\
\hline CDKN3 & Cyclin-dependent kinase inhibitor 3 & 10.58 & NM_005192.2 \\
\hline TK1 & Thymidine kinase 1 & 10.57 & NM 003258.1 \\
\hline AURKB & Aurora kinase B & 10.28 & $\underline{\text { NM } 004217.1}$ \\
\hline ASPM & Asp (abnormal spindle)-like, microcephaly associated & 10.27 & $\underline{\text { NM } 018136.2}$ \\
\hline OIP5 & Opa interacting protein 5 & 10.13 & NM_007280.1 \\
\hline TRIP13 & Thyroid hormone receptor interactor 13 & 10.04 & $\underline{\text { NM } 004237.2}$ \\
\hline MCM7 & Minichromosome maintenance complex component 7 & 9.87 & NM 182776.1 \\
\hline FLJ40629 & Cytoskeleton associated protein 2-like & 9.83 & NM_152515.2 \\
\hline CEP55 & Centrosomal protein $55 \mathrm{kDa}$ & 9.77 & NM_018131.3 \\
\hline PBK & PDZ binding kinase & 9.50 & $\underline{\text { NM } 018492.2}$ \\
\hline RRM2 & Ribonucleotide reductase M2 polypeptide & 9.44 & NM 001034.1 \\
\hline STMN1 & Stathmin 1/oncoprotein 18 & 9.12 & NM_005563.3 \\
\hline HCAP-G & Non-SMC condensin I complex, subunit G & 8.70 & $\underline{\text { NM } 022346.3}$ \\
\hline HIST1H4C & Histone cluster 1 & 8.61 & NM 003542.3 \\
\hline CENPM & Centromere protein $\mathrm{M}$ & 8.61 & $\underline{\text { NM } 001002876.1}$ \\
\hline AURKA & Aurora kinase A & 8.53 & NM_198434.1 \\
\hline PLK4 & Polo-like kinase 4 & 8.41 & NM 014264.2 \\
\hline AURKA & Aurora kinase A & 8.38 & NM 198434.1 \\
\hline CENPA & Centromere protein $\mathrm{A}, 17 \mathrm{kDa}$ & 7.99 & NM_001809.2 \\
\hline DLG7 & Discs, large homolog 7 & 7.92 & NM 014750.3 \\
\hline CDCA8 & Cell division cycle associated 8 & 7.83 & $\underline{\text { NM } 018101.2}$ \\
\hline TPX2 & TPX2, microtubule-associated, homolog & 7.60 & NM 012112.4 \\
\hline C20orf129 & Chromosome 20 open reading frame 129 & 7.45 & NM_030919.1 \\
\hline RAD51AP1 & RAD51 associated protein 1 & 7.18 & NM_006479.2 \\
\hline TTK & TTK protein kinase & 6.99 & NM 003318.3 \\
\hline MCM5 & MCM5 minichromosome maintenance deficient 5, cell division cycle 46 & 6.97 & $\underline{\text { NM } 006739.2}$ \\
\hline MCM4 & MCM4 minichromosome maintenance deficient 4 & 6.95 & $\underline{\text { NM } 005914.2}$ \\
\hline LMNB1 & Lamin B1 & 6.41 & NM_005573.2 \\
\hline MPHOSPH1 & M-phase phosphoprotein 1 & 6.39 & NM 016195.2 \\
\hline
\end{tabular}


Table 4b. Genes with significantly higher expression in expanded MSC capable to form bone after subcutaneous transplantation in SCID mice (continued - part 2).

\begin{tabular}{|c|c|c|c|}
\hline BUB1 & BUB1 budding uninhibited by benzimidazoles 1 & 6.35 & $\underline{\text { NM } 004336.2}$ \\
\hline SPC24 & SPC24, NDC80 kinetochore complex component & 6.19 & NM 182513.1 \\
\hline FANCD2 & Fanconi anemia, complementation group D2 & 5.91 & $\underline{\text { NM_001018115.1 }}$ \\
\hline MCM7 & Minichromosome maintenance complex component 7 & 5.80 & NM_005916.3 \\
\hline МСМ3 & MCM3 minichromosome maintenance deficient 3 & 5.69 & $\underline{\text { NM_002388.3 }}$ \\
\hline ANLN & Anillin, actin binding protein & 5.66 & $\underline{\text { NM } 018685.2}$ \\
\hline FKSG14 & Leucine zipper protein FKSG14 & 5.57 & $\underline{\text { NM } 022145.2}$ \\
\hline KIF2C & Kinesin family member $2 \mathrm{C}$ & 5.56 & $\underline{\text { NM_006845.2 }}$ \\
\hline NCAPG2 & Non-SMC condensin II complex, subunit G2 & 5.52 & NM_017760.5 \\
\hline PRR11 & Proline rich 11 (PRR11), mRNA. & 5.51 & $\underline{\text { NM } 018304.1}$ \\
\hline POLE2 & Polymerase (DNA directed), epsilon 2 (p59 subunit) & 5.45 & NM 002692.2 \\
\hline CDC2 & Cell division cycle $2, \mathrm{G} 1$ to $\mathrm{S}$ and $\mathrm{G} 2$ to $\mathrm{M}$ & 5.43 & NM 033379.2 \\
\hline МCM2 & MCM2 minichromosome maintenance deficient 2, mitotin & 5.41 & NM_004526.2 \\
\hline C16orf60 & Centromere protein $\mathrm{N}$ & 5.39 & $\underline{\text { NM_018455.3 }}$ \\
\hline FOXM1 & Forkhead box M1 & 5.37 & $\underline{\text { NM } 021953.2}$ \\
\hline DKFZp762E1312 & Hypothetical protein DKFZp762E1312 & 5.32 & $\underline{\text { NM } 018410.2}$ \\
\hline AРОВЕС3B & Apolipoprotein B mRNA editing enzyme, catalytic polypeptide-like 3B & 5.25 & $\underline{\text { NM_004900.3 }}$ \\
\hline FEN1 & Flap structure-specific endonuclease 1 & 5.22 & NM_004111.4 \\
\hline MELK & Maternal embryonic leucine zipper kinase & 5.21 & NM_014791.2 \\
\hline EXO1 & Exonuclease 1 & 5.18 & $\underline{\text { NM } 003686.3}$ \\
\hline SOCS2 & Suppressor of cytokine signaling 2 & 5.11 & $\underline{\mathrm{NM}} 0003877.3$ \\
\hline CENPF & Centromere protein F, 350/400ka & 4.99 & $\underline{\text { NM_016343.3 }}$ \\
\hline UBE2T & Ubiquitin-conjugating enzyme E2T & 4.97 & NM_014176.1 \\
\hline C22orf18 & Centromere protein $\mathrm{M}$ & 4.94 & $\underline{\text { NM } 024053.3}$ \\
\hline CDK2 & Cyclin-dependent kinase 2 & 4.89 & NM 001798.2 \\
\hline PRIM1 & Primase, polypeptide $1,49 \mathrm{kDa}$ & 4.86 & $\underline{\text { NM } 000946.2}$ \\
\hline RFC4 & Replication factor C (activator 1) $4,37 \mathrm{kDa}$ & 4.84 & NM_002916.3 \\
\hline KIF4A & Kinesin family member $4 \mathrm{~A}$ & 4.83 & NM_012310.2 \\
\hline TMPO & Thymopoietin & 4.80 & $\underline{\text { NM } 003276.1}$ \\
\hline FLJ25416 & Chromosome 11 open reading frame 82 & 4.77 & NM_145018.2 \\
\hline RPL39L & Ribosomal protein L39-like & 4.76 & $\underline{\text { NM } 052969.1}$ \\
\hline RRM1 & Ribonucleotide reductase M1 polypeptide & 4.75 & $\underline{\text { NM } 001033.2}$ \\
\hline RACGAP1 & Rac GTPase activating protein 1 & 4.67 & NM_013277.2 \\
\hline DNAJC9 & DnaJ (Hsp40) homolog, subfamily C, member 9 & 4.58 & $\underline{\text { NM } 015190.3}$ \\
\hline POLQ & Polymerase (DNA directed), theta & 4.56 & $\underline{\text { NM } 199420.2}$ \\
\hline GTSE1 & G-2 and S-phase expressed 1 & 4.55 & NM_016426.4 \\
\hline CDT1 & Chromatin licensing and DNA replication factor 1 & 4.55 & NM_030928.2 \\
\hline HAS2 & Hyaluronan synthase 2 & 4.52 & NM_005328.1 \\
\hline RFC3 & Replication factor C (activator 1) $3,38 \mathrm{kDa}$ & 4.50 & $\underline{\text { NM } 181558.1}$ \\
\hline SMC4 & Structural maintenance of chromosomes 4 & 4.48 & $\underline{\text { NM } 001002800.1}$ \\
\hline WDR51A & WD repeat domain $51 \mathrm{~A}$ & 4.44 & NM_015426.2 \\
\hline CCNE2 & Cyclin E2 & 4.38 & NM_057735.1 \\
\hline TROAP & Trophinin associated protein (tastin) & 4.37 & $\underline{\text { NM } 005480.2}$ \\
\hline MCM6 & MCM6 minichromosome maintenance deficient 6 & 4.33 & $\underline{\text { NM } 005915.4}$ \\
\hline ATAD2 & ATPase family, AAA domain containing 2 & 4.33 & NM 014109.2 \\
\hline CENPM & Centromere protein $\mathrm{M}$ & 4.26 & NM_001002876.1 \\
\hline CKS1B & $\mathrm{CDC} 28$ protein kinase regulatory subunit $1 \mathrm{~B}$ & 4.21 & $\underline{\text { NM_001826.1 }}$ \\
\hline CCNF & Cyclin F & 4.15 & $\underline{\text { NM } 001761.1}$ \\
\hline
\end{tabular}


Table 4c. Genes with significantly higher expression in expanded MSC capable to form bone after subcutaneous transplantation in SCID mice (continued - part 3).

\begin{tabular}{|c|c|c|c|}
\hline KIF23 & Kinesin family member 23 & 4.15 & NM 004856.4 \\
\hline CDCA3 & Cell division cycle associated 3 & 4.05 & NM 031299.3 \\
\hline RFC5 & Replication factor C (activator 1) 5 & 4.05 & NM 007370.3 \\
\hline KIF14 & Kinesin family member 14 & 3.95 & $\underline{\text { NM } 014875.1}$ \\
\hline SUV39H1 & Suppressor of variegation 3-9 homolog 1 & 3.95 & $\underline{\mathrm{NM}} 003173.1$ \\
\hline H2AFZ & H2A histone family, member $\mathrm{Z}$ & 3.93 & NM 002106.3 \\
\hline MCM10 & Minichromosome maintenance complex component 10 & 3.88 & $\underline{\mathrm{NM} \quad 018518.3}$ \\
\hline HMMR & Hyaluronan-mediated motility receptor & 3.80 & NM 012484.1 \\
\hline DDX39 & DEAD (Asp-Glu-Ala-Asp) box polypeptide 39 & 3.79 & NM_005804.2 \\
\hline CENPA & Centromere protein $\mathrm{A}$ & 3.78 & NM 001042426.1 \\
\hline NUDT1 & Nudix (nucleoside diphosphate linked moiety X)-type motif 1 & 3.73 & NM 198948.1 \\
\hline CHAF1B & Chromatin assembly factor 1 , subunit B (p60) & 3.71 & NM 005441.2 \\
\hline RFC3 & Replication factor C (activator 1) 3, 38kDa & 3.64 & NM_002915.2 \\
\hline DNMT1 & DNA (cytosine-5-)-methyltransferase 1 & 3.64 & $\underline{\text { NM } 001379.1}$ \\
\hline C6orf173 & Chromosome 6 open reading frame 173 & 3.60 & NM 001012507.1 \\
\hline FLJ20364 & Hypothetical protein FLJ20364 & 3.59 & NM 017785.2 \\
\hline MCM4 & Minichromosome maintenance complex component 4 & 3.56 & NM 182746.1 \\
\hline PLK1 & Polo-like kinase 1 & 3.52 & NM 005030.3 \\
\hline TIMELESS & Timeless homolog & 3.52 & NM 003920.2 \\
\hline PSRC1 & Proline/serine-rich coiled-coil 1 & 3.51 & NM_001005290.2 \\
\hline PAQR4 & Progestin and adipoQ receptor family member IV & 3.47 & $\underline{\mathrm{NM} 152341.2}$ \\
\hline HNRPA1 & Heterogeneous nuclear ribonucleoprotein A1 & 3.42 & NM_002136.1 \\
\hline BARD1 & BRCA1 associated RING domain 1 & 3.39 & NM_000465.1 \\
\hline KIAA0101 & KIAA0101 & 3.36 & $\underline{\mathrm{NM} \quad 014736.4}$ \\
\hline RFC4 & Replication factor C (activator 1) 4, 37kDa & 3.33 & $\underline{\mathrm{NM} 002916.3}$ \\
\hline SGOL1 & Shugoshin-like 1 & 3.30 & NM_001012413.1 \\
\hline SKP2 & S-phase kinase-associated protein 2 (p45) & 3.30 & $\underline{\mathrm{NM} 032637.2}$ \\
\hline CCDC34 & Coiled-coil domain containing 34 & 3.29 & NM 030771.1 \\
\hline CHEK1 & CHK1 checkpoint homolog & 3.24 & NM 001274.2 \\
\hline CDC25A & Cell division cycle $25 \mathrm{~A}$ & 3.24 & $\underline{\mathrm{NM} 001789.2}$ \\
\hline GPSM2 & G-protein signalling modulator 2 & 3.22 & $\underline{\mathrm{NM} 013296.3}$ \\
\hline ZWILCH & Zwilch, kinetochore associated, homolog & 3.20 & $\underline{\text { NR_003105.1 }}$ \\
\hline EZH2 & Enhancer of zeste homolog 2 & 3.19 & NM_152998.1 \\
\hline CNAP1 & Non-SMC condensin I complex, subunit D2 & 3.18 & NM 014865.2 \\
\hline EZH2 & Enhancer of zeste homolog 2 & 3.17 & NM_004456.3 \\
\hline RPA3 & Replication protein $\mathrm{A} 3,14 \mathrm{kDa}$ & 3.17 & $\underline{\text { NM_002947.3 }}$ \\
\hline RBMX & RNA binding motif protein, $\mathrm{X}$-linked & 3.15 & $\underline{\mathrm{NM} 002139.2}$ \\
\hline LIG1 & Ligase I, DNA, ATP-dependent & 3.15 & $\underline{\mathrm{NM} \quad 000234.1}$ \\
\hline BIRC5 & Baculoviral IAP repeat-containing 5 (survivin) & 3.13 & NM 001012271.1 \\
\hline CACYBP & Calcyclin binding protein & 3.11 & NM 014412.2 \\
\hline FUS & Fusion (involved in $\mathrm{t}(12 ; 16)$ in malignant liposarcoma) & 3.09 & NM 004960.2 \\
\hline NUSAP1 & Nucleolar and spindle associated protein 1 & 3.07 & NM 018454.5 \\
\hline LBR & Lamin B receptor & 3.06 & $\underline{\mathrm{NM} 002296.2}$ \\
\hline TACC3 & Transforming, acidic coiled-coil containing protein 3 & 3.05 & $\underline{\mathrm{NM} 006342.1}$ \\
\hline C18orf24 & Chromosome 18 open reading frame 24 & 3.05 & NM_145060.1 \\
\hline PPIL5 & Peptidylprolyl isomerase (cyclophilin)-like 5 & 3.04 & NM_152329.3 \\
\hline HNRPA2B1 & Heterogeneous nuclear ribonucleoprotein A2/B1 & 3.03 & NM 031243.1 \\
\hline ASF1B & ASF1 anti-silencing function 1 homolog B & 3.02 & NM_018154.2 \\
\hline
\end{tabular}


Table 4d. Genes with significantly higher expression in expanded MSC capable to form bone after subcutaneous transplantation in SCID mice (continued - part 4).

\begin{tabular}{|c|c|c|c|}
\hline POLA2 & Polymerase (DNA directed), alpha 2 (70kD subunit) & 3.02 & $\underline{\mathrm{NM} 002689.2}$ \\
\hline ILF3 & Interleukin enhancer binding factor $3,90 \mathrm{kDa}$ & 2.99 & NM 004516.2 \\
\hline BCL2L12 & BCL2-like 12 (proline rich) & 2.98 & $\underline{\mathrm{NM} \quad 052842.2}$ \\
\hline RNASEH2A & Ribonuclease $\mathrm{H} 2$, subunit A & 2.95 & $\underline{\text { NM_006397.2 }}$ \\
\hline C17orf53 & Chromosome 17 open reading frame 53 & 2.93 & $\underline{\mathrm{NM} 024032.2}$ \\
\hline KIF15 & Kinesin family member 15 & 2.93 & $\underline{\mathrm{NM}} \mathbf{0 2 0 2 4 2 . 1}$ \\
\hline FOXM1 & Forkhead box M1 & 2.92 & NM_202002.1 \\
\hline BCL2L12 & BCL2-like 12 (proline rich) & 2.91 & $\underline{\text { NM } 001040668.1}$ \\
\hline TFAM & Transcription factor A, mitochondrial & 2.89 & $\underline{\mathrm{NM}} \mathbf{0 0 3 2 0 1 . 1}$ \\
\hline EXOSC9 & Exosome component 9 & 2.83 & $\underline{\mathrm{NM}} \mathbf{0 0 5 0 3 3 . 1}$ \\
\hline E2F2 & E2F transcription factor 2 & 2.82 & $\underline{\text { NM_004091.2 }}$ \\
\hline MNS1 & Meiosis-specific nuclear structural 1 & 2.78 & $\underline{\mathrm{NM} 018365.1}$ \\
\hline FLJ13912 & GINS complex subunit 3 & 2.75 & NM_022770.2 \\
\hline CDC25C & Cell division cycle 25 homolog $\mathrm{C}$ & 2.73 & $\underline{\text { NM_001790.3 }}$ \\
\hline DIAPH3 & Diaphanous homolog 3 & 2.72 & NM 001042517.1 \\
\hline SLC25A15 & Solute carrier family 25 (mitochondrial carrier; ornithine transporter) member 15 & 2.72 & $\underline{\mathrm{NM} 014252.2}$ \\
\hline SNRPB & Small nuclear ribonucleoprotein polypeptides B and B1 & 2.71 & $\underline{\text { NM_003091.3 }}$ \\
\hline MCM10 & Minichromosome maintenance complex component 10 & 2.70 & $\underline{\mathrm{NM} 018518.3}$ \\
\hline FLJ13909 & Hypothetical protein FLJ13909 & 2.63 & $\underline{\text { NM } 025108.1}$ \\
\hline BLM & Bloom syndrome & 2.58 & $\underline{\mathrm{NM} 000057.1}$ \\
\hline POLA1 & Polymerase (DNA directed), alpha 1 & 2.56 & $\underline{\text { NM_016937.2 }}$ \\
\hline LSM2 & LSM2 homolog, U6 small nuclear RNA associated & 2.56 & $\underline{\text { NM } 021177.3}$ \\
\hline GEMIN6 & Gem (nuclear organelle) associated protein 6 & 2.55 & $\underline{\text { NM_024775.9 }}$ \\
\hline EIF2B2 & Eukaryotic translation initiation factor $2 \mathrm{~B}$, subunit $2 \mathrm{beta}, 39 \mathrm{kDa}$ & 2.54 & NM_014239.2 \\
\hline FLJ22624 & FLJ22624 protein & 2.53 & $\underline{\mathrm{NM} 024808.2}$ \\
\hline CBX5 & Chromobox homolog 5 & 2.52 & $\underline{\mathrm{NM}} 012117.1$ \\
\hline SNRPB & Small nuclear ribonucleoprotein polypeptides B and B1 & 2.50 & $\underline{\mathrm{NM} 003091.3}$ \\
\hline CDC25C & Cell division cycle 25 homolog $\mathrm{C}$ & 2.49 & $\underline{\mathrm{NM} 001790.3}$ \\
\hline HNRPM & Heterogeneous nuclear ribonucleoprotein $\mathrm{M}$ & 2.47 & $\underline{\mathrm{NM}} \mathbf{0 3 1 2 0 3 . 1}$ \\
\hline C2orf32 & Chromosome 2 open reading frame 32 & 2.46 & $\underline{\text { NM_015463.1 }}$ \\
\hline LMNB2 & Lamin B2 & 2.45 & $\underline{\text { NM } 032737.2}$ \\
\hline CGGBP1 & CGG triplet repeat binding protein 1 & 2.45 & $\underline{\mathrm{NM} 003663.3}$ \\
\hline DKFZP564J0863 & DKFZP564J0863 protein & 2.44 & $\underline{\mathrm{NM}} 015459.3$ \\
\hline GALE & UDP-galactose-4-epimerase & 2.44 & $\underline{\text { NM_000403.3 }}$ \\
\hline SLD5 & GINS complex subunit 4 & 2.43 & $\underline{\mathrm{NM}} \mathbf{0 3 2 3 3 6 . 1}$ \\
\hline NPM3 & Nucleophosmin/nucleoplasmin, 3 & 2.43 & $\underline{\text { NM_006993.1 }}$ \\
\hline CSE1L & CSE1 chromosome segregation 1-like & 2.42 & $\underline{\mathrm{NM} 001316.2}$ \\
\hline SMC2L1 & SMC2 structural maintenance of chromosomes 2-like 1 & 2.39 & $\underline{\mathrm{NM} \quad 006444.1}$ \\
\hline PFAS & Phosphoribosylformylglycinamidine synthase & 2.38 & $\underline{\text { NM } 012393.1}$ \\
\hline EXOSC2 & Exosome component 2 & 2.37 & $\underline{\mathrm{NM} 014285.4}$ \\
\hline TUBB2C & Tubulin, beta $2 \mathrm{C}$ & 2.36 & $\underline{\mathrm{NM} 006088.5}$ \\
\hline INCENP & Inner centromere protein antigens $135 / 155 \mathrm{kDa}$ & 2.36 & $\underline{\text { NM } 001040694.1}$ \\
\hline SNRPA & Small nuclear ribonucleoprotein polypeptide A & 2.34 & $\underline{\text { NM_004596.3 }}$ \\
\hline CDK2 & Cyclin-dependent kinase 2 & 2.34 & $\underline{\text { NM } 001798.2}$ \\
\hline C16orf61 & Chromosome 16 open reading frame 61 & 2.34 & $\underline{\text { NM } 020188.2}$ \\
\hline RPS7 & Ribosomal protein $\mathrm{S} 7$ & 2.33 & $\underline{\mathrm{NM}} \mathbf{0 0 1 0 1 1 . 3}$ \\
\hline PDSS1 & Prenyl (decaprenyl) diphosphate synthase, subunit 1 & 2.33 & $\underline{\text { NM_014317.3 }}$ \\
\hline SAAL1 & Serum amyloid A-like 1 & 2.32 & $\underline{\text { NM } 138421.1}$ \\
\hline
\end{tabular}


Table 4e. Genes with significantly higher expression in expanded MSC capable to form bone after subcutaneous transplantation in SCID mice (continued - part 5).

\begin{tabular}{|c|c|c|c|}
\hline MRPL35 & Mitochondrial ribosomal protein L35 & 2.32 & NM_145644.1 \\
\hline SNRPF & Small nuclear ribonucleoprotein polypeptide $\mathrm{F}$ & 2.31 & $\underline{\text { NM } 003095.2}$ \\
\hline ХTPЗТРA & XTP3-transactivated protein A & 2.29 & $\underline{\mathrm{NM} \quad 024096.1}$ \\
\hline NUP37 & Nucleoporin $37 \mathrm{kDa}$ & 2.28 & NM 024057.2 \\
\hline C18orf55 & Chromosome 18 open reading frame 55 & 2.26 & NM 014177.1 \\
\hline MRPL11 & Mitochondrial ribosomal protein L11 & 2.25 & $\underline{\mathrm{NM} 016050.2}$ \\
\hline MRPL39 & Mitochondrial ribosomal protein L39 & 2.24 & $\underline{\mathrm{NM} 017446.2}$ \\
\hline CCDC5 & Coiled-coil domain containing 5 & 2.23 & $\underline{N M \_138443.2}$ \\
\hline C1orf33 & Chromosome 1 open reading frame 33 . & 2.20 & $\underline{\mathrm{NM} 016183.2}$ \\
\hline MGC13170 & Chromosome 19 open reading frame 48 & 2.19 & NM_199249.1 \\
\hline SNRPG & Small nuclear ribonucleoprotein polypeptide G & 2.19 & NM_003096.2 \\
\hline RPL29 & Ribosomal protein L29 & 2.19 & $\underline{\mathrm{NM} 000992.2}$ \\
\hline STRA13 & Stimulated by retinoic acid 13 homolog & 2.18 & $\underline{N M \_144998.2}$ \\
\hline EMG1 & EMG1 nucleolar protein homolog & 2.17 & $\underline{\mathrm{NM} 006331.4}$ \\
\hline POLE3 & Polymerase (DNA directed), epsilon 3 (p17 subunit) & 2.17 & $\underline{\text { NM } 017443.3}$ \\
\hline MRRF & Mitochondrial ribosome recycling factor & 2.16 & $\underline{\text { NM_138777.2 }}$ \\
\hline SMS & Spermine synthase & 2.12 & NM_004595.2 \\
\hline ТМЕМ97 & Transmembrane protein 97 & 2.11 & $\underline{\text { NM } 014573.1}$ \\
\hline FLJ14668 & Family with sequence similarity 136, member A & 2.10 & $\underline{\mathrm{NM} \quad 032822.1}$ \\
\hline RPL36A & Ribosomal protein L36a & 2.09 & NM_021029.4 \\
\hline TUBA6 & Tubulin, alpha 1c & 2.08 & NM_032704.2 \\
\hline SLC25A5 & Solute carrier family 25 (mitochondrial carrier; adenine nucleotide translocator), member 5 & 2.07 & NM 001152.1 \\
\hline STOML2 & Stomatin (EPB72)-like 2 & 2.06 & NM_013442.1 \\
\hline MRPS31 & Mitochondrial ribosomal protein S31 & 2.05 & NM 005830.2 \\
\hline CARKL & Carbohydrate kinase-like & 2.05 & $\underline{\mathrm{NM} 013276.2}$ \\
\hline HMBS & Hydroxymethylbilane synthase & 2.03 & $\underline{\mathrm{NM} 001024382.1}$ \\
\hline C9orf40 & Chromosome 9 open reading frame 40 & 1.99 & NM_017998.1 \\
\hline SUHW4 & Suppressor of hairy wing homolog 4 & 1.98 & $\underline{\mathrm{NM}} 0001002844.1$ \\
\hline MRPL12 & Mitochondrial ribosomal protein L12 & 1.98 & $\underline{\mathrm{NM} \quad 002949.2}$ \\
\hline NAT10 & $\mathrm{N}$-acetyltransferase 10 & 1.98 & NM_024662.1 \\
\hline NXT1 & NTF2-like export factor 1 & 1.97 & $\underline{\text { NM } 013248.2}$ \\
\hline BANF1 & Barrier to autointegration factor 1 & 1.97 & $\underline{\mathrm{NM} \quad 003860.2}$ \\
\hline HPRT1 & Hypoxanthine phosphoribosyltransferase 1 & 1.96 & NM_000194.1 \\
\hline NUP85 & Nucleoporin $85 \mathrm{kDa}$ & 1.93 & $\underline{\text { NM_024844.2 }}$ \\
\hline RFWD3 & Ring finger and WD repeat domain 3 & 1.89 & $\underline{\mathrm{NM} 018124.3}$ \\
\hline DUSP12 & Dual specificity phosphatase 12 & 1.84 & NM 007240.1 \\
\hline C20orf20 & Chromosome 20 open reading frame 20 & 1.80 & NM_018270.3 \\
\hline ADSL & Adenylosuccinate lyase & 1.75 & $\underline{\mathrm{NM} \quad 000026.1}$ \\
\hline
\end{tabular}


Table 5. Genes with significantly higher expression in expanded MSC which were not able to form bone after subcutaneous transplantation in SCID mice.

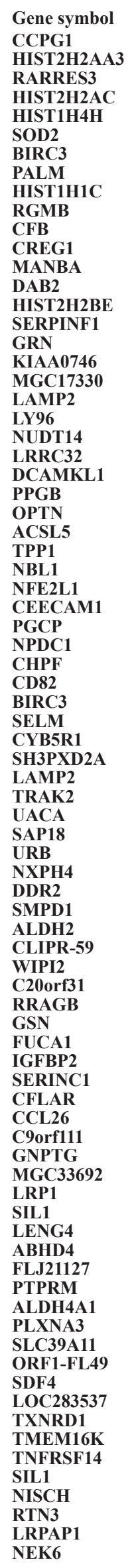

Gene name

Cell cycle progression 1

Histone cluster 2, $\mathrm{H} 2$ aa3

Retinoic acid receptor responder (tazarotene induced) 3

Histone cluster 2, H2ac

Histone cluster $1, \mathrm{H} 4 \mathrm{~h}$

Superoxide dismutase 2, mitochondrial

Baculoviral IAP repeat-containing 3

Paralemmin

Histone cluster 1, H1c

RGM domain family, member B

Complement factor B

Cellular repressor of E1A-stimulated genes 1

Mannosidase, beta A, lysosomal

Disabled homolog 2

Histone cluster 2, $\mathrm{H} 2 \mathrm{be}$

Serpin peptidase inhibitor, clade $\mathrm{F}$

Granulin

KIAA0746 protein

Phosphoinositide-3-kinase interacting protein 1

Lysosomal-associated membrane protein 2

Lymphocyte antigen 96

Nudix (nucleoside diphosphate linked moiety X)-type motif 14

Leucine rich repeat containing 32

Doublecortin and CaM kinase-like 1

Protective protein for beta-galactosidase

Optineurin

Acyl-CoA synthetase long-chain family member 5

Tripeptidyl peptidase I

Neuroblastoma, suppression of tumorigenicity 1

Nuclear factor (erythroid-derived 2)-like 1

Cerebral endothelial cell adhesion molecule 1

Plasma glutamate carboxypeptidase

Neural proliferation, differentiation and control

Chondroitin polymerizing factor

CD82 antigen

Baculoviral IAP repeat-containing 3

Selenoprotein M

Cytochrome b5 reductase 1

$\mathrm{SH} 3$ and $\mathrm{PX}$ domains $2 \mathrm{~A}$

Lysosomal-associated membrane protein 2

Trafficking protein, kinesin binding 2

Uveal autoantigen with coiled-coil domains and ankyrin repeats

Sin3A-associated protein

Coiled-coil domain containing 80

Neurexophilin 4

Discoidin domain receptor family, member 2

Sphingomyelin phosphodiesterase 1 , acid lysosomal

Aldehyde dehydrogenase 2 family

CAP-GLY domain containing linker protein 3

WD repeat domain, phosphoinositide interacting 2

ER degradation enhancer, mannosidase alpha-like 2

Ras-related GTP binding B

Gelsolin

Fucosidase, alpha-L- 1, tissue

Insulin-like growth factor binding protein 2

Serine incorporator 1

CASP8 and FADD-like apoptosis regulator

Chemokine (C-C motif) ligand 26

Patatin-like phospholipase domain containing 7

N-acetylglucosamine-1-phosphate transferase, gamma subunit

Similar to RIKEN cDNA 1700027 J05 gene

Low density lipoprotein-related protein 1

SIL1 homolog, endoplasmic reticulum chaperone

Leukocyte receptor cluster

Abhydrolase domain containing 4

Tectonic

Protein tyrosine phosphatase, receptor type

Aldehyde dehydrogenase 4 family, member A1

Plexin A3

Solute carrier family 39 (metal ion transporter), member 11

Putative nuclear protein ORF1-FL49

Stromal cell derived factor 4

Hypothetical protein LOC283537

Thioredoxin reductase 1

Transmembrane protein $16 \mathrm{~K}$

Tumor necrosis factor receptor superfamily, member 14

SIL1 homolog, endoplasmic reticulum chaperone

Nischarin

Reticulon 3

Low density lipoprotein receptor-related protein associated protein 1

NIMA (never in mitosis gene a)-related kinase 6
Fold change to

bone forming

MSC populations Reference

$\begin{array}{ll}6.6 & \mathrm{NM} 004748.3 \\ 6.4 & \mathrm{NM} 003516.2\end{array}$

5.4

$5.1 \quad \underline{\mathrm{NM}} \quad 003517.2$

$4.7 \quad \mathrm{NM} 003543.3$

4.7

4.5

4.5

4.5
4.4

4.4

4.1
4.0

4.0
3.9

3.8

3.7

3.7
3.7

3.7
3.5

3.5

3.5
3.4

3.3

3.3

3.3
3.3

3.3
3.2

3.2

3.1

3.1
3.0

3.0

3.0

3.0
2.9

2.9

2.9

2.9
2.8

2.8
2.8

NM 001165.3

$\frac{\text { NM } 002579.1}{\text { NM } 005319.3}$

NM 001012761.1

NM 001710.4

NM-003851.2

NM 005908.2

NM 001343.1

NM 003528.2

NM 002615.4

NM 002087.2

NM 015187.1

NM 052880.3

NM 002294.1

NM 015364.2

NM 177533.2

NM 005512.1

NM 004734.2

NM 000308.1

NM 001008213.1

NM 203379.1

NM 000391.2

NM 005380.4

NM 003204.

NM 016174.3

NM 016134.2

NM 015392.2

NM 024536.4

NM 002231.3

NM 182962.1

NM 080430.2

NM 016243.2

NM 014631.2

NM 002294.1

NM 015049.1

NM 018003.2

$\mathrm{NM} 005870.3$

NM 199512.1

NM 007224.1

NM 006182.2

NM 001007593.1

NM 000690.2

NM 015526.1

NM 016003.3

NM 018217.1

NM 006064.3

NM 198252.1

NM 000147.2

NM 000597.2

NM 020755.2

NM 003879.3

NM 006072.4

NM 152286.2

NM 032520.3

NM 001001794.1

NM 002332.1

NM 001037633.1

NM 024298.2

NM 022060.2

NM 024549.3

NM 002845.2

NM 170726.1

NM 017514.2

NM 139177.2

NM 032412.2

NM 016547.1

NM 181785.

NM 003330.2

NM 018075.2

NM 003820.2

NM 022464.3

NM 007184.2

NM 201430.1

NM 002337.1

NM 014397.3 
stimuli and a supporting bone-environment did not exist? One explanation may be that, in the first place, a high anabolism is needed to create an active microenvironment at the site of transplantation which allows activation of local cells and attraction of blood vessels in order to satisfy the enhanced demand for nutrients and oxygen for building up new bone tissue. Only if this trophic action of MSC is successfully achieved, possibly through a high amount of secreted factors, sufficient cells survive, stay in place and do more than integrating at low efficiency into fibrous tissue deposited by invading mouse cells. A second crucial aspect of a high proliferation rate and anabolism may be related to the mesengenic activity of MSC. In order to cope with the new $3 \mathrm{D}$ conditions after transplantation and the differentiation into osteoblasts, regulatory gene regions that the cell has probably never used before, may need to be accessed. DNA condensing molecules like histones and nucleosome-forming molecules were significantly higher expressed in non-bone forming MSC having a generation time above $43 \mathrm{~h}$ and being in culture for longer than 18 days. This provides indirect evidence of a time window of more open chromatin up to this time point which may be crucial to allow cell adaptation including initiation of the in vivo osteogenic differentiation cascade. A third possibility to explain the important role of proliferation may be the need for high cell anabolism to create an environment allowing sufficient release of calcium-phosphate ions from the $\beta$-TCP scaffold. This could render the carrier more osteoinductive and may drive osteogenic in vivo differentiation of human MSC. For clinical application, MSC can well be transplanted in the context of this scaffold since its complete degradation or resorption allows that it can fully be replaced by newly formed bone (Jensen et al., 2006; Okuda et al., 2007). Unfortunately, it was not possible to document and correlate the degree of resorption of $\beta$-TCP to proliferation rate, because the radio-opaque shadows of newly built bone obtained by quantitative micro-computed tomography could not be discriminated from those of the ceramic.

Remarkably, enhanced conditions adapted from embryonal stem cell expansion were able to rescue the bone forming ability of inferior MSC in agreement with an enhanced proliferation rate, extending the permissive window to later time points in culture. Overall it is tempting to speculate that, in general, a high anabolism may be a rate limiting parameter crucial for therapeutic applications in which the trophic activity of MSC is important like in myocardial infarction. On top of this, open chromatin may be further relevant if differentiation and thus mesengenic activity is required to allow cells to contribute physically to repair tissue due to their plasticity. In contrast to this, MSC with inhibited proliferation were unable to form bone in vivo, showing again the correlation between growth and osteogenic in vivo potency. In Fig. 3, at first sight, mitomycin C-treated cells seemed to be half as vital as untreated MSC that may be caused by a toxicity of the reagent. However, these values were not normalised to the DNA content of the wells and generation time at seeding of untreated MSC suggests that cells expanded about twofold during the assay, while mitomycin C-treated MSC were unable to proliferate. Taking this into consideration, there is almost no difference in MSC vitality between both groups giving no hints on a toxicity of the chosen standard mitomycin $\mathrm{C}$ concentration on MSC.

One important question is why the dominant role of growth for therapeutic potency was so far unrecognised. First, there are only a few studies which systematically addressed the donor variability of primary human MSC in the context of a desired in vivo outcome. Among studies addressing donor-dependent features of bone formation (Mendes et al., 2002; Mendes et al., 2004; Siddappa et al., 2007; De Bari et al., 2008) only two studies comprised more than 5 donors and in both a osteogenic pre-induction protocol was applied before transplantation (Mendes et al., 2002; Mendes et al., 2004). Second, opposite to clinical application, where sorting out of inferior cell populations is not possible since the donors require a treatment, researchers frequently work only with the best cell populations leaving those of inferior growth behind. Third, investigators usually do not know the number of multipotent MSC in their starting cultures which can differ by more than 100-fold per mononuclear cell fraction according to colony-forming assays (Majors et al., 1997; Muschler et al., 2001). Thus, some MSC populations may have already undergone 7-10 more population doublings before first confluency compared to others with seeding density being an additional parameter to influence the replicative potential of MSC (Phinney, 2002). Thus, the usual "standardisation" of cultures by passage number falls short in reflecting comparable conditions between donors and may hide this correlation unless a high number of donor populations are investigated, as done in this study.

Although a sharp threshold of around $43 \mathrm{~h}$ per population doubling was here suggested to separate boneforming from non-bone-forming MSC, indeed a time span of several hours existed (between $43 \mathrm{~h}$ and about 60 $\mathrm{h}$ per population doubling), within which the generation time alone could not fully predict the in vivo outcome in the heterotopic model. In single cases, non-cellular parameters related to the mouse or the transplantation procedure may have prevented bone formation as evident from gene expression profiling of MSC from donor 10, which perfectly matched other bone forming samples in cluster analysis of gene expression (Fig. 4), but was unable to form bone in vivo. Obviously however, at a still permissive proliferation rate between 43 and $60 \mathrm{~h}$, other factors become relevant which further influence the degree of bone formation in vivo. Interestingly, increased overrepresentation of extracellular matrix genes was recently reported to characterise the molecular phenotype of a human MSC clone with bone-forming capacity at lower population level compared to high population level when heterotopic bone formation was lost (Larsen et al., 2010). Since this MSC line grows indefinitely due to stable expression of the human telomerase reverse-transcriptase (hTERT) gene, speed of proliferation may not be ratelimiting allowing extracting further predictors beyond proliferation rate like expression of decorin or natriuretic peptide-receptor- $\mathrm{C}$ which were, however, not extracted in our transcriptome analysis.

Genes known as positive regulators of osteogenesis like ALP, Runx2, osteopontin, osteocalcin or bone sialoprotein 
were not significantly up-regulated in our gene expression profiling of undifferentiated MSC populations. Before transplantation, there was also no significant difference regarding the expression of osteogenic genes between bone-forming MSC populations and MSC without the ability to form bone. This demonstrates that the contamination of MSC populations with osteoblasts or partly differentiated osteogenic progenitor cells, although present to some extent, was no prominent factor influencing bone formation. This suggests that the high proliferation rate of a large fraction of MSC in a population outcompeted the possible advantage by a fraction of cells that may already have taken the first steps to become an osteoblast. The highly ordered deposition of bone towards the $\beta$-TCP scaffold pores suggests that the capacity to deposit a mineralised matrix is spatially controlled and the fittest MSC to achieve this may be fast proliferating rather than pre-differentiated cells.

Importantly, in vitro mineral deposition did not correlate with the in vivo bone formation in our study and this disqualified the standard osteogenic in vitro assay as a correlate of heterotopic bone formation ability of human MSC. This is in line with another study showing that ex vivo matrix mineralisation assays lack specificity, may be confounded by precipitation of calcium phosphate and show surprisingly poor concordance with bone formation in vivo (Larsen et al., 2010). Overall, this questions the usefulness of in vitro mineralisation to define "multilineage capacity" of mesenchymal cell populations. In contrast to mineralisation, ALP activity during in vitro osteogenesis seemed to be a more specific parameter to predict the osteogenic in vivo potency of human MSC. Peak ALP values were chosen for statistical correlation since the time course of ALP up-regulation was distinct between donors, and day 21 provided not always the highest values. Our results showed that optimum in vitro ALP activity was a growth-related parameter and highlighted again the correlation to and importance of proliferation.

Altered expansion conditions will require determination of a new threshold level for generation time as predictor, and the heterotopic bone formation model applied here cannot be used to conclude about the bone formation ability of MSC in a bony defect. If bone is formed at an ectopic site in the absence of a supporting bone environment, it is however likely that the same cells will also be able to form bone orthotopically in a bony lesion. Nevertheless, observations from an adequate orthotopic model are required to decide about the importance of high proliferation rate and open chromatin for neo-bone formation in a setting closer to clinical application.

Since age-related changes were reported for human MSC (Stolzing et al., 2008), people with inferior stem cells in bone marrow aspirates might exist. Most importantly our data promise that all aspects ensuring fast but limited expansion of MSC, like use of sufficient MSC at start of culture, enhanced growth conditions, and careful calculation of the number of cells to be transplanted, may pave the way for promising therapeutic application of MSC from elderly donors given a successful potency testing before transplantation.

\section{Conclusion}

In conclusion, therapeutic efficiency of MSC may strongly depend on their trophic and mesengenic "fitness" which in our study correlated with a short generation time and, thus, high anabolism. We demonstrated that proliferation of MSC is a rate-limiting determinant of heterotopic bone formation, established a causal relationship between growth and engraftment and introduced a potency test allowing prediction of in vivo bone forming ability with high sensitivity and specificity.

Rather than identifying unsuitable donors, we suggest that MSC have to be transplanted in a time window in which sufficient cells show high anabolism as major prerequisite for trophic and mesengenic activity.

\section{Acknowledgements}

We would like to thank RMS Foundation (Bettlach, Switzerland) for providing $\beta$-TCP granules. We are grateful to the physicians of the Department of Orthopaedic Surgery, Orthopaedic University Hospital Heidelberg, for providing bone marrow samples. Furthermore, we thank Simone Gantz for statistical data analysis and Katharina Mazur and Birgit Frey for technical assistance.

\section{References}

Agata H, Asahina I, Watanabe N, Ishii Y, Kubo N, Ohshima S, Yamazaki M, Tojo A, Kagami H (2010) Characteristic change and loss of in vivo osteogenic abilities of human bone marrow stromal cells during passage. Tissue Eng Part A 16: 663-673.

Bruder SP, Kraus KH, Goldberg VM, Kadiyala S (1998a) The effect of implants loaded with autologous mesenchymal stem cells on the healing of canine segmental bone defects. J Bone Joint Surg Am 80: 985-996.

Bruder SP, Kurth AA, Shea M, Hayes WC, Jaiswal N, Kadiyala S (1998b) Bone regeneration by implantation of purified, culture-expanded human mesenchymal stem cells. J Orthop Res 16: 155-162.

Caplan AI (2009) Why are MSCs therapeutic? New data: new insight. J Pathol 217: 318-324.

De Bari C, Dell'Accio F, Karystinou A, Guillot PV, Fisk NM, Jones EA, McGonagle D, Khan IM, Archer CW, Mitsiadis TA, Donaldson AN, Luyten FP, Pitzalis C (2008) A biomarker-based mathematical model to predict bone-forming potency of human synovial and periosteal mesenchymal stem cells. Arthritis Rheum 58: 240-250.

Dennis G, Jr., Sherman BT, Hosack DA, Yang J, Gao W, Lane HC, Lempicki RA (2003) DAVID: Database for Annotation, Visualization, and Integrated Discovery. Genome Biol 4: 3.

Dickhut A, Pelttari K, Janicki P, Wagner W, Eckstein V, Egermann M, Richter W (2009) Calcification or dedifferentiation: requirement to lock mesenchymal stem cells in a desired differentiation stage. J Cell Physiol 219: 219-226. 
Digirolamo CM, Stokes D, Colter D, Phinney DG, Class R, Prockop DJ (1999) Propagation and senescence of human marrow stromal cells in culture: a simple colonyforming assay identifies samples with the greatest potential to propagate and differentiate. Br J Haematol 107: 275-281.

Eisen MB, Spellman PT, Brown PO, Botstein D (1998) Cluster analysis and display of genome-wide expression patterns. Proc Natl Acad Sci U S A 95: 14863-14868.

Hernigou P, Mathieu G, Poignard A, Manicom O, Beaujean F, Rouard H (2006) Percutaneous autologous bone-marrow grafting for nonunions. Surgical technique. J Bone Joint Surg Am 88 Suppl 1: 322-327.

Huang DW, Sherman BT, Lempicki RA (2009) Systematic and integrative analysis of large gene lists using DAVID bioinformatics resources. Nat Protoc 4: 44-57.

Jaiswal N, Haynesworth SE, Caplan AI, Bruder SP (1997) Osteogenic differentiation of purified, cultureexpanded human mesenchymal stem cells in vitro. J Cell Biochem 64: 295-312.

Janicki P, Kasten P, Kleinschmidt K, Luginbuehl R, Richter W (2010) Chondrogenic pre-induction of human mesenchymal stem cells on beta-TCP: enhanced bone quality by endochondral heterotopic bone formation. Acta Biomater 6: 3292-3301.

Jensen SS, Broggini N, Hjorting-Hansen E, Schenk R, Buser D (2006) Bone healing and graft resorption of autograft, anorganic bovine bone and beta-tricalcium phosphate. A histologic and histomorphometric study in the mandibles of minipigs. Clin Oral Implants Res 17: 237-243.

Krebsbach PH, Kuznetsov SA, Satomura K, Emmons RV, Rowe DW, Robey PG (1997) Bone formation in vivo: comparison of osteogenesis by transplanted mouse and human marrow stromal fibroblasts. Transplantation 63: 1059-1069.

Kuznetsov SA, Mankani MH, Robey PG (2000) Effect of serum on human bone marrow stromal cells: ex vivo expansion and in vivo bone formation. Transplantation 70: 1780-1787.

Larsen KH, Frederiksen CM, Burns JS, Abdallah BM, Kassem M (2010) Identifying a molecular phenotype for bone marrow stromal cells with in vivo bone-forming capacity. J Bone Miner Res 25: 796-808.

Lazarus HM, Haynesworth SE, Gerson SL, Caplan AI (1997) Human bone marrow-derived mesenchymal (stromal) progenitor cells (MPCs) cannot be recovered from peripheral blood progenitor cell collections. J Hematother 6: 447-455.

Majors AK, Boehm CA, Nitto H, Midura RJ, Muschler GF (1997) Characterization of human bone marrow stromal cells with respect to osteoblastic differentiation. J Orthop Res 15: 546-557.

Mannello F, Tonti GA (2007) Concise review: no breakthroughs for human mesenchymal and embryonic stem cell culture: conditioned medium, feeder layer, or feeder-free; medium with fetal calf serum, human serum, or enriched plasma; serum-free, serum replacement nonconditioned medium, or ad hoc formula? All that glitters is not gold! Stem Cells 25: 1603-1609.

Martin I, Muraglia A, Campanile G, Cancedda R, Quarto R (1997) Fibroblast growth factor-2 supports ex vivo expansion and maintenance of osteogenic precursors from human bone marrow. Endocrinology 138: 4456-4462.

Matsushima A, Kotobuki N, Tadokoro M, Kawate K, Yajima H, Takakura Y, Ohgushi H (2009) In vivo osteogenic capability of human mesenchymal cells cultured on hydroxyapatite and on beta-tricalcium phosphate. Artif Organs 33: 474-481.

McLain RF, Fleming JE, Boehm CA, Muschler GF (2005) Aspiration of osteoprogenitor cells for augmenting spinal fusion: comparison of progenitor cell concentrations from the vertebral body and iliac crest. J Bone Joint Surg Am 87: 2655-2661.

Mendes SC, Tibbe JM, Veenhof M, Bakker K, Both S, Platenburg PP, Oner FC, de Bruijn JD, van Blitterswijk CA (2002) Bone tissue-engineered implants using human bone marrow stromal cells: effect of culture conditions and donor age. Tissue Eng 8: 911-920.

Mendes SC, Tibbe JM, Veenhof M, Both S, Oner FC, van Blitterswijk CA, de Bruijn JD (2004) Relation between in vitro and in vivo osteogenic potential of cultured human bone marrow stromal cells. J Mater Sci Mater Med 15: 1123-1128.

Metz CE, Goodenough DJ, Rossmann K (1973) Evaluation of receiver operating characteristic curve data in terms of information theory, with applications in radiography. Radiology 109: 297-303.

Muraglia A, Martin I, Cancedda R, Quarto R (1998) A nude mouse model for human bone formation in unloaded conditions. Bone 22: 131S-134S.

Muschler GF, Boehm C, Easley K (1997) Aspiration to obtain osteoblast progenitor cells from human bone marrow: the influence of aspiration volume. J Bone Joint Surg Am 79: 1699-1709.

Muschler GF, Nitto H, Boehm CA, Easley KA (2001) Age- and gender-related changes in the cellularity of human bone marrow and the prevalence of osteoblastic progenitors. J Orthop Res 19: 117-125.

Okuda T, Ioku K, Yonezawa I, Minagi H, Kawachi G, Gonda Y, Murayama H, Shibata Y, Minami S, Kamihira S, Kurosawa H, Ikeda T (2007) The effect of the microstructure of beta-tricalcium phosphate on the metabolism of subsequently formed bone tissue. Biomaterials 28: 2612-2621.

Phinney DG (2002) Building a consensus regarding the nature and origin of mesenchymal stem cells. J Cell Biochem Suppl 38: 7-12.

Phinney DG (2007) Biochemical heterogeneity of mesenchymal stem cell populations: clues to their therapeutic efficacy. Cell Cycle 6: 2884-2889.

Phinney DG, Kopen G, Righter W, Webster S, Tremain N, Prockop DJ (1999) Donor variation in the growth properties and osteogenic potential of human marrow stromal cells. J Cell Biochem 75: 424-436.

Pietila M, Lehtonen S, Narhi M, Hassinen IE, Leskela HV, Aranko K, Nordstrom K, Vepsalainen A, Lehenkari P (2010) Mitochondrial function determines the viability and osteogenic potency of human mesenchymal stem cells. Tissue Eng Part C Methods 16: 435-445.

Platt MO, Wilder CL, Wells A, Griffith LG, Lauffenburger DA (2009) Multipathway kinase signatures of multipotent stromal cells are predictive for osteogenic 
differentiation: tissue-specific stem cells. Stem Cells 27: 2804-2814.

Reyes M, Lund T, Lenvik T, Aguiar D, Koodie L, Verfaillie CM (2001) Purification and ex vivo expansion of postnatal human marrow mesodermal progenitor cells. Blood 98: 2615-2625.

Rickard DJ, Kassem M, Hefferan TE, Sarkar G, Spelsberg TC, Riggs BL (1996) Isolation and characterization of osteoblast precursor cells from human bone marrow. J Bone Miner Res 11: 312-324.

Russell KC, Phinney DG, Lacey MR, Barrilleaux BL, Meyertholen KE, O'Connor KC (2010) In vitro highcapacity assay to quantify the clonal heterogeneity in trilineage potential of mesenchymal stem cells reveals a complex hierarchy of lineage commitment. Stem Cells 28: 788-798.

Shahdadfar A, Fronsdal K, Haug T, Reinholt FP, Brinchmann JE (2005) In vitro expansion of human mesenchymal stem cells: choice of serum is a determinant of cell proliferation, differentiation, gene expression, and transcriptome stability. Stem Cells 23: 1357-1366.

Siddappa R, Licht R, van Blitterswijk C, de Boer J (2007) Donor variation and loss of multipotency during in vitro expansion of human mesenchymal stem cells for bone tissue engineering. J Orthop Res 25: 1029-1041.

Siddappa R, Martens A, Doorn J, Leusink A, Olivo C, Licht R, van Rijn L, Gaspar C, Fodde R, Janssen F, van Blitterswijk C, de Boer J (2008) cAMP/PKA pathway activation in human mesenchymal stem cells in vitro results in robust bone formation in vivo. Proc Natl Acad Sci USA 105: 7281-7286.

Sotiropoulou PA, Perez SA, Salagianni M, Baxevanis CN, Papamichail M (2006) Characterization of the optimal culture conditions for clinical scale production of human mesenchymal stem cells. Stem Cells 24: 462-471.

Steck E, Burkhardt M, Ehrlich H, Richter W (2010) Discrimination between cells of murine and human origin in xenotransplants by species specific genomic in situ hybridization. Xenotransplantation 17: 153-159.

Stenderup K, Justesen J, Clausen C, Kassem M (2003) Aging is associated with decreased maximal life span and accelerated senescence of bone marrow stromal cells. Bone 33: 919-926.

Stolzing A, Jones E, McGonagle D, Scutt A (2008) Age-related changes in human bone marrow-derived mesenchymal stem cells: consequences for cell therapies. Mech Ageing Dev 129: 163-173.

Tarte K, Gaillard J, Lataillade JJ, Fouillard L, Becker M, Mossafa H, Tchirkov A, Rouard H, Henry C, Splingard M, Dulong J, Monnier D, Gourmelon P, Gorin NC, Sensebe L (2010) Clinical-grade production of human mesenchymal stromal cells: occurrence of aneuploidy without transformation. Blood 115: 1549-1553.

Wagner W, Ho AD (2007) Mesenchymal stem cell preparations - comparing apples and oranges. Stem Cell Rev 3: 239-248.

Winter A, Breit S, Parsch D, Benz K, Steck E, Hauner H, Weber RM, Ewerbeck V, Richter W (2003) Cartilagelike gene expression in differentiated human stem cell spheroids: a comparison of bone marrow-derived and adipose tissue-derived stromal cells. Arthritis Rheum 48: 418-429.

Zweig MH, Campbell G (1993) Receiver-operating characteristic (ROC) plots: a fundamental evaluation tool in clinical medicine. Clin Chem 39: 561-577.

\section{Discussion with Reviewers}

Reviewer I: Density gradient isolated bone marrow cells were used in the present study. The authors call these cells "mesenchymal stem cells" but further characterisation is missing (cell surface marker profile, differentiation capacity, minimal criteria, see Dominici et al. (2006). It is therefore suggested that these cells are not called "mesenchymal stem cells" but "bone marrow stromal cells". Please comment.

Authors: We call the cells in our study "mesenchymal stem cells" because we routinely screen them for the expression pattern of defined clusters of differentiation as recommended by the International Society for Cellular Therapy (Dominici et al., 2006). We have previously published cell surface marker profiles for MSC from bone marrow, adipose tissue and synovial membrane (Dickhut et al., 2009, text reference). Additionally, we always convince ourselves of the multipotency of the isolated MSC by differentiating the cell populations towards the osteogenic, adipogenic and chonrogenic lineage (Winter et al., 2003, text reference).

Reviewer I: Can you speculate which cells might be more effective for therapeutical use: stem cells or bone marrow stromal cells?

Authors: While bone marrow stromal cells were recognised as the niche cells supporting haematopoietic stem cells in bone, mesenchymal stem cells are naturally found as perivascular cells in many tissues which are released at sites of injury to secrete large quantities of bioactive factors. Since both cell types seem to have the capacity to build up new mesenchymal tissue, the term "mesenchymal stem cell" and "bone marrow stromal cell" is often used as a synonym for a cell population with tissue regeneration potential derived from bone marrow. Due to the lack of a specific marker profile to distinguish bone marrow stromal cells from mesenchymal stem cells it is difficult to tell which cell entity has higher stem cell character. Their effectivity for therapeutic use may depend on many factors, not only on their origin in the body.

Reviewer II: It is known that ALK activity is dependent on the levels of Mg. Did the authors measure the levels of magnesium in the mice as this may have little to do with the stem cells. Mg depletion can reduce ALK phosphatase and osteoblast activity?

Authors: No, we did not measure the level of magnesium in our animals. Since they were fed with magnesiumcontaining food $(0.22 \%)$, we expected physiological levels in all animals, but cannot exclude a magnesium effect on bone formation. Importantly, ALP activity was assessed only in vitro in this study and not in the transplanted 
$\beta$-TCP/MSC-constructs, thus here a magnesium effect can be excluded.

Reviewer II: Why did mitomycin-treated cells deposit a mineralised matrix in vitro?

Authors: Mitomycin C-treated MSC were shown to be unable to proliferate on the one hand but were still vital as shown by the WST assay (see Fig. 3). Consequently, when cells are vital, they are able to answer to extrinsic stimuli like induction media. In our case, MSC answered to osteogenic in vitro stimuli showing that proliferation was not necessary for the deposition of calcified matrix. This was in sharp contrast to the in vivo situation where the ability to proliferate was essential for successful bone formation and showed again, that the in vitro mineralisation assay is not informative about the bone forming potency of human MSC.

Reviewer II: Wouldn't it be better to use clones?

Authors: We used non-clonal MSC populations to be close to the clinical situation. Cloning is unattractive since MSC clones are not stable. So after expansion of clones, one ends up with a heterogeneous cell population derived from one cell.

Reviewer II: The conclusions are based on the scaffold and have very little to do with the clinic. Please comment. Authors: Our conclusion is based on a scaffold with high osteo-permissive features which were demonstrated and compared in a previous study (Janicki et al., 2010, text reference). Human MSC do not form ectopic bone without any scaffold. Thus, we made the decision to choose $\beta$-TCP as a matrix frequently used in orthopaedic surgery. MSC could well be transplanted in context with such granules in patients.

\section{Additional Reference}

Dominici M, Le Blanc K, Mueller I, Slaper-Cortenbach I, Marini F, Krause D, Deans R, Keating A, Prockop Dj, Horwitz E (2006) Minimal criteria for defining multipotent mesenchymal stromal cells. The International Society for Cellular Therapy position statement. Cytotherapy 8: 315317. 